\title{
Characterization and Reclamation Assessment for the Central Shops Diesel Storage Facility at Savannah River Site ${ }^{(U)}$
}

Westinghouse Savannah River Company

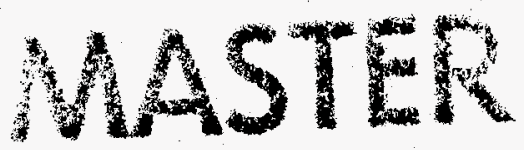




\section{DISCLATMER}

This report was prepared as an account of work sponsored by an agency of the United States Government. Neither the United States Government nor any agency thereof, nor any of their Government. Neither the United States Government nor any agcacy thes any legal liability or
employees, makes any warranty, express or implied, or assumes any
responsibility for the accuracy, completeness, or usefulness of any information, apparatus, product, or process disclosed, or represents that its use wroduct, process, or service by trade name, Reference herein to any specific commercial predsarily constitute or imply its endorsement, trademark; manufacturer, or otherwise does not states Government or any agency thereof. The recommendation, or favoring by the United So not-necessarily state or reflect those of the views and opinions of authors expressed hereen.

This report has been reproduced directly from the best available copy.

Available to DOE and DOE contractors from the Office of Scientific and Technical Information, P.O. Box 62, Oak Ridge, TN 37831; prices available from (615) 576-8401.

Available to the public from the National Technical Information Service, U.S. Department of Commerce, 5285 Port Royal Road, Springfield, VA 22161. 


\section{DISCLAIMER}

Portions of this document may be illegible in electronic image products. Images are produced from the best available original document. 
WSRC-TR-94-0344

Rev 0

\section{Characterization and Reclamation Assessment for the Central Shops Diesel Storage Facility $(U)$}

C. B. Fliermans, T. C. Hazen, and H. W. Bledsoe

Authentication:

Prepared for the U.S. Department of Energy under contract no. DE-AC09-89SR18035

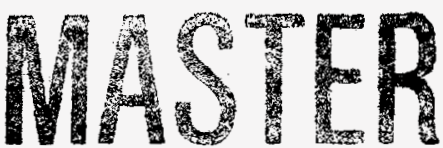




\section{Contents}

1.0 Introduction $\ldots \ldots \ldots \ldots \ldots \ldots \ldots \ldots \ldots \ldots \ldots \ldots \ldots \ldots, 1$

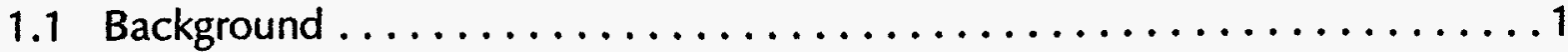

1.2 Program Overview........................................

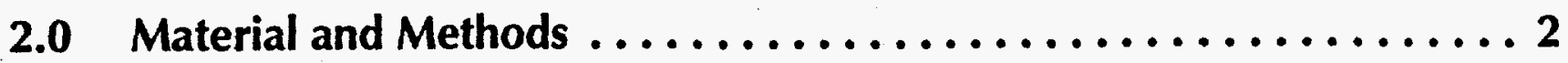

2.1 Site Geological Description ...............................

2.2 Geology and Hydrology of Diesel Storage Facility Site $\ldots \ldots \ldots \ldots \ldots \ldots .2$

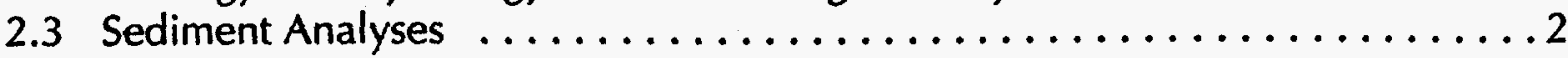

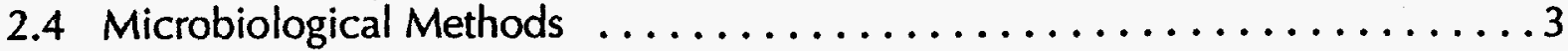

3.0 Results and Discussion $\ldots \ldots \ldots \ldots \ldots \ldots \ldots \ldots \ldots \ldots \ldots, \ldots$

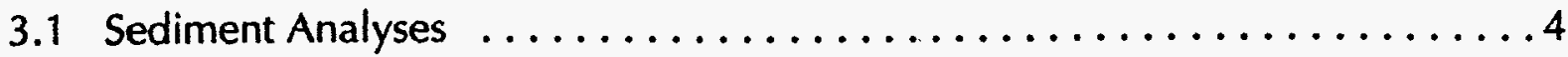

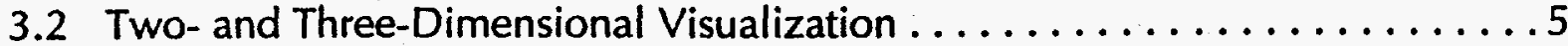

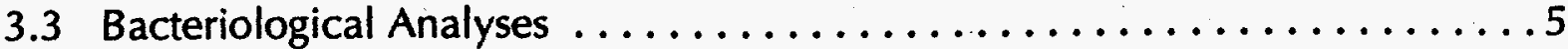

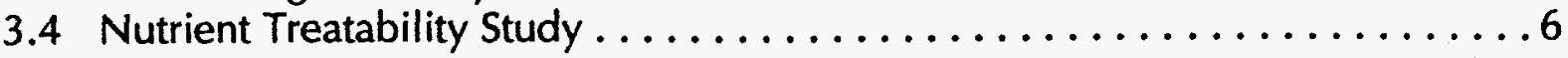

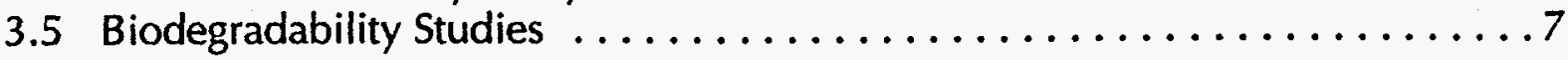

4.0 Conclusions and Recommendations $\ldots \ldots \ldots \ldots \ldots \ldots \ldots \ldots$

5.0 References $\ldots \ldots \ldots \ldots \ldots \ldots \ldots \ldots \ldots \ldots \ldots \ldots \ldots, \ldots \ldots \ldots$

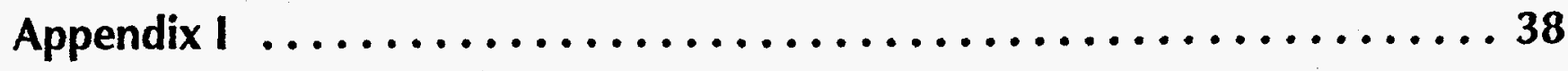

Appendix II .............................47

List of Tables

1. Grain-size Distribution for Sediments Collected at Selected Intervals at the CSDSF Site

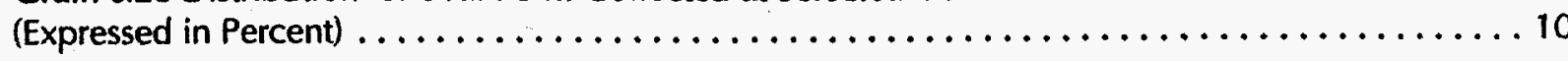

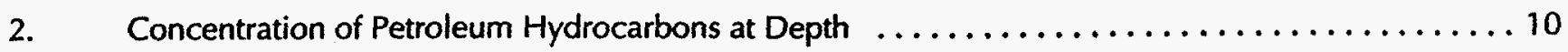

3. Concentration of Lead at Depth in the Sediments of Central Shops Diesel Storage Facility . . . . . . 11

4. Maximum Concentration of Lead in the Groundwater and Sediments of Central Shops

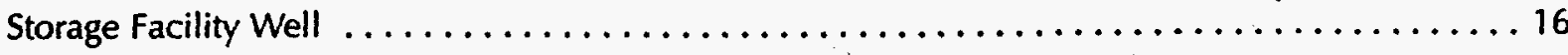


5. Densities of Total Heterotrophic and Diesel Utilizing Bacteria in Sediments Containing Total Petroleum Hydrocarbons from Central Shops Diesel Fuel Facility with Respect

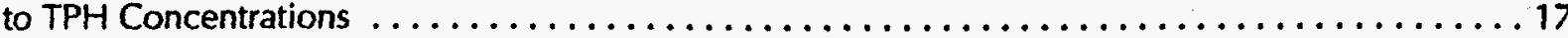

6. Amendments and Concentrations Used in Biodegradability Investigations $\ldots \ldots \ldots \ldots \ldots \ldots 18$

7. Cell Yields $(\mathrm{mg} / \mathrm{L})$ for Combinations of Inorganic Nutrients $\ldots \ldots \ldots \ldots \ldots \ldots \ldots \ldots \ldots$

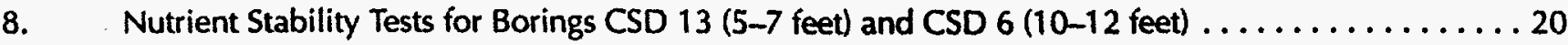

9. Column Investigations of Groundwater Flow Rate through Columns Packed with

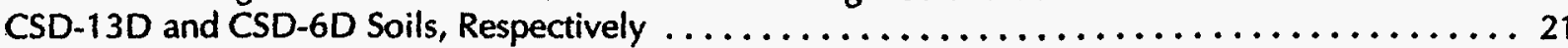

\section{List of Figures}

1. Location of the Central Shops Diesel Storage Facility . . . . . . . . . . . . . . . . 22

2. Characterization Area at Central Shops Diesel Storage Facility $\ldots \ldots \ldots \ldots \ldots \ldots \ldots \ldots \ldots$

3. Concentration of Methane in Soil Gas (Expressed in Percentage) $\ldots \ldots \ldots \ldots \ldots \ldots \ldots \ldots . \ldots \ldots$

4. Generalized Stratigraphic Section at the Savannah River Site $\ldots \ldots \ldots \ldots \ldots \ldots \ldots \ldots \ldots \ldots$

5. Contour Mapping of Water Table Elevations for Central Shops Diesel Storage

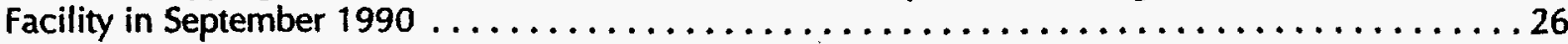

6. Two-dimensional Contour Mapping of Maximum Total Petroleum Hydrocarbons at $100 \mathrm{ppm}$ Intervals for Sediments 0 to 19 feet below the Soil Surface . . . . . . . . . . . . 27

7. Two-dimensional Contour Mapping of Maximum Total Petroleum Hydrocarbons at $100 \mathrm{ppm}$ Intervals for Sediments 20 to 39 feet below the Soil Surface . . . . . . . . . . . . 28

8. Two-dimensional Contour Mapping of Maximum Total Petroleum at $100 \mathrm{ppm}$ Intervals for Sediments 40 to 59 feet below the Soil Surface . . . . . . . . . . . . . . . . . . . 29

9. Two-dimensional Contour Mapping of MBotal Petroleum Hydrocarbons at $100 \mathrm{ppm}$ Intervals for Sediments at Depth below the Soil Surface (a) $\ldots \ldots \ldots \ldots \ldots \ldots \ldots \ldots$

10. Three-dimensional Contour Mapping of Maximum Total Petroleum Hydrocarbons at $100 \mathrm{ppm}$ Intervals for Sediments at Depth below the Soil Surface (b) $\ldots \ldots \ldots \ldots \ldots \ldots \ldots \ldots$

11. Three-dimensional Contour Mapping of Maximum Total Petroleum Hydrocarbons at $100 \mathrm{ppm}$ Intervals for Sediments at Depth below the Soil Surface (c) $\ldots \ldots \ldots \ldots \ldots \ldots \ldots \ldots$

12. Three-dimensional Contour Mapping of Maximum Total Petroleum Hydrocarbons at $100 \mathrm{ppm}$ Intervals for Sediments at Depth below the Soil Surface (d) $\ldots \ldots \ldots \ldots \ldots \ldots \ldots$

13. Biological Degradation of Biological Volatile TPH in Laboratory Microcosms with a Variety of Amendments . . . . . . . . . . . . . . . . . . . . . . . . . . . . . 35

14. Biological Degradation of TPH in Laboratory Microcosms with a Variety of Amendments .......36

15. Vacuum Extraction of CSD-13D Soils Containing TPH $\ldots \ldots \ldots \ldots \ldots \ldots \ldots \ldots \ldots \ldots \ldots \ldots$ 


\title{
Characterization and Reclamation Assessment of the Central Shops Diesel Storage Facility at the Savannah River Site (U)
}

\author{
C. B. Fliermans, T. C. Hazen, and H. W. Bledsoe
}

\begin{abstract}
The contamination of subsurface terrestrial environments by organic contaminants is a global phenomenon. The remediation of such environments requires innovative assessment techniques and strategies for successful cleanups. Using innovative approaches, the Central Shops Diesel Storage Facility at the Savannah River Site (SRS) was characterized to determine the extent of subsurface diesel fuel contamination. Effective bioremediation techniques for cleaning up of the contaminant plume were established.
\end{abstract}

\subsection{Introduction}

This report summarizes the environmental characterization data and a bioreclamation feasibility assessment for the Central Shops Diesel Storage Area at the Savannah River Site (SRS) in Aiken, South Carolina, and it is a part of a remedial action investigation of the contaminated soils and sediments at the Central Shops Diesel Storage Area.

\subsection{Background}

Groundwater and vadose zone sediments throughout the world have become contaminated with industrial and agricultural wastes over the centuries. Abelson (1989) tried to place the problem in perspective in that as many as 375,000 underground storage tanks in the United States have leaked and endangered groundwater systems. The problem is far more extensive than underground storage tanks and the North American continent. The,problem is not unique to American soils; Poland, for example, reported that during the last 20 years approximately 40,000 tons of highly toxic agricultural wastes have been buried in Poland. Such estimates appear highly underestimated and the real volumes are likely to be as much as $100 \%$ higher (Amador 1992).

Abelson also pointed out that the cleanup of groundwater contamination often requires $20-40$ years, costing over $\$ 500$ billion using the current cost-effective technologies. A technology that promises to reduce these costs, yet provide an effective cleanup, is bioremediation, the use of indigenous biological processes to destroy or immobilize contaminants. Traditionally, scientists have underestimated the power, capabilities, and diversity of the subsurface microbial communities. The usefulness of indigenous microorganisms for in situ bioremediation of groundwater and sediment pollutants was documented in Integrated Demonstration Program at SRS (Hazen 1991) and provides new mechanisms for remediating subsurface environments contaminated with organic wastes.

Underground storage tanks at the Central Shops Diesel Storage Facility (CSDSF) at SRS (Figures 1 and 2) were installed in 1955. The tank farm contained 10 underground carbon steel storage tanks, each holding 15,000 gallons. The facility was used to store diesel fuels and occasionally gasoline. In December 1987, water that leaked from an underground water line near the CSDSF contained petroleum hydrocarbons. The contamination was presumed to be from handling and storing diesel fuel, although other contamination sources were in this area. Tanks suspected of leaking were taken out of service and a soil gas survey was conducted to determine whether hydrocarbons had leaked into the surrounding soil (Looney et al. 1988). The soil gas survey detected high concentrations of volatile components in diesel fuel. Large amounts of methane were also being produced (Figure 3), indicating biological degradation of the diesel fuel in the soils.

The characterization study for the CSDSF began in November 1988 and consisted of sampling and analyzing the shallow soils, sediments, and groundwater to determine the extent, both vertical and horizontal, of the diesel 
fuel contamination. The feasibility of bioremediation as an option for remediating the site was then be determined from this characterization study.

\subsection{Program Overview}

The remediation goal for the CSDSF is to cost effectively reduce the contamination levels of petroleum hydrocarbons in the subsurface environment to levels that are acceptable to both SRS and regulatory agencies. This will be accomplished in a stepped approach initiated by extensive site characterization and feasibility investigations for possible remediation technologies.

The assessment portion of the investigation was separated into two sets of drilling and analyses operations. Initially, 29 boreholes were drilled from the surface to the water table (60 feet) while sampling at three-foot intervals using both split-spoon sampling technologies for sediments and Hydropunch technology (Manchon 1992) to collect groundwater samples. The location of each of these boreholes is given in Figure 2. Total petroleum hydrocarbons (TPH), total bacterial densities, indigenous microbiological degraders of diesel fuel, and selected inorganic compounds were measured. Nine boreholes (CSD-1D, CSD2D, CSD-4, CSD-8D, CSD-9D-CSD-13D) were continuously cored and lithologically described. Monitoring wells were then installed at each of these boreholes and the geology and hydrology of the sediments and aquifer were defined. The data for each of these wells were published in Fliermans et al. (1993). Nutrient optimization investigations were conducted to determine the following:

- the best nutrients to stimulate the indigenous microbial populations

- whether such additions were compatible with sediments at the CSDSF

\subsection{Material and Methods}

\subsection{Site Geological Description}

The Savannah River Site is located approximately $40 \mathrm{~km}$ from the upper (landward) margin of the Atlantic Coastal Plain and approximately $120 \mathrm{~km}$ from the current ocean margin. The elevation of the land's surface at SRS ranges from 25 to $125 \mathrm{~m}$ above mean sea level. The wedge of sediments beneath SRS ranges from approximately $200 \mathrm{~m}$ in thickness at the northern boundary to approximately 400 $m$ at the southern boundary. A generalized stratigraphic section appears in Figure 4. The geology of the site was described by Sargent and Fliermans (1989).

\subsection{Geology and Hydrology of Diesel Storage Facility Site}

The CSDSF site contains 4-6 feet of topsoil, which is generally underlain by 15 feet of mottled clay or sandy clay. Poorly sorted and tightly packed sands and clayey sands with numerous small silty clay seams are beneath the clay layer. The sands become more cross-bedded with depth and generally contain less clay. A perched groundwater table was encountered in several borings at approximately 25 feet below land surface at the top of a sandy clay interval.

The mineral composition of three sediment samples from CSD-9D was determined by $x$-ray diffraction analyses. Two samples, from 62 to 64 feet and 66 to 67 feet respectively, were predominantly quartz sand with a small amount of kaolinite. The third sample (67-68 feet) was a mixture of quartz with minor amounts of hornblende, kaolinite, and aragonite. The grain-size distribution is given in Table 1.

\subsection{Sediment Analyses}

Based on data from the soil gas survey (Looney et al. 1988), a drilling program, designed to characterize both the lateral and vertical extent of the diesel contamination in the soil, was conducted from December 1988 through January 1989. All soil samples were collected from the first 13 boreholes (see Figure 1), analyzed for TPH by extraction with EPA Methods 3540 and 9071, and quantified using EPA Method 418.1. EPA Method 3540 was a soxhlet extraction with freon, while EPA 418.1 involved cleaning up the freon extract with silica gel to remove nonhydrocarbon components and quantifying the TPHs by infrared analyses (FTIR). The minimum detectable limit for laboratory analysis was $1 \mathrm{mg} / \mathrm{kg}$; however, all values less than $5 \mathrm{mg} / \mathrm{kg}$ were considered below detectable limits. Spiked recoveries for the assays averaged $80 \%$. All groundwater samples were below detectable limits of less than $1.0 \mathrm{ppm}$ for TPHs (Table 2). (The U.S. Army Corp of Engineers performed cone penetrometer investigations using fiber optic hardware to confirm, in real time, the concentrations of TPH and at which depth and to identify additional contamination, if present.)

The concentrations of selected inorganic nutrients in the groundwater was also determined by inductively coupled plasma emission spectrometry for selected metals and anions. Specific attention was given to lead concentrations since the storage tanks at the facility had occasionally contained leaded gasoline. Total lead analyses of the 
sediments and water were conducted using EPA Method 239.2 protocol with laboratory control standards within the control limits of 80-120\% recovery. All water samples were processed within the holding times required by 40 CFR 136 (EPA), although holding times for soil and sediment samples have not been promulgated by EPA at this time. The data in Table 3 indicate the concentration of lead in the sediments for the boreholes, while the data in Table 4 shows the concentration of lead in the groundwater for screened wells along with maximum concentration of lead found in the sediments of a given borehole.

Dissolved aluminum was detected in the groundwater and ranged in concentration from 1.2 to $4.6 \mathrm{mg} / \mathrm{L}$. The only other metals found above the detection level were zinc at $0.06 \mathrm{mg} / \mathrm{L}$ in CSD-4D and iron at $1.26 \mathrm{mg} / \mathrm{L}$ in CSD-13D and $3.95 \mathrm{mg} / \mathrm{L}$ in CSD-11D. The presence of dissolved iron in the groundwater at moderate concentrations may make it difficult to add oxygen to the system because of the fouling by iron oxidized floc if in situ bioreclamation is chosen as the remedial alternative. Well CSD-4D contained higher levels of calcium, sodium, and potassium than the other two wells. Most inorganic nutrients required for microbial growth were present, although probably not at levels necessary for maximum growth and biodegradation of the organic contaminants. Nitrogen, as nitrate, was also present in the groundwater, ranging from 0.6 to 1.6 $\mathrm{mg} / \mathrm{L}$. Nitrite was not detected. Ortho-phosphate levels were below $5 \mathrm{mg} / \mathrm{L}$. Other minerals required for microbial growth such as magnesium, manganese, potassium, sodium, chloride, and sulfate were found in low quantities in almost all of the samples.

\subsection{Microbiological Methods}

Sediment samples were collected for microbial investigations as previously described (Phelps et al. 1989), and density and physiological characteristics of the indigenous microbial populations were determined. Biological activity, as measured by colony-forming units (CFUs), was conducted on the soil, sediment, and groundwater samples using standard microbiological plating techniques. The total heterotrophic microbial population was enumerated on Difco@ (Detroit, MI, U.S.A.) nutrient agar using the pour plate techniques. Bacterial populations capable of using hydrocarbons were plated on a mineral salts medium with diesel fuel hydrocarbons as the sole carbon source. The mineral salts medium contained washed agar and essential inorganic nutrients. Three drops of the diesel fuel were placed on a filter paper in the inverted lid of the petri dish; the diesel vapors provided the carbon for growth of the hydrocarbon-utilizing microorganisms. Groundwater from the site was filter-sterilized and used as the dilutant. All samples were plated within 24 to 36 hours of collection. Total heterotrophic bacteria populations were enumerated after a seven-day incubation period at $20^{\circ} \mathrm{C}$, and the hydrocarbon utilizers were counted after 26 days. Microbial counts for both the heterotrophic populations grown on plate count agar and diesel-utilizing (DU) bacteria are presented in Table 5.

\subsubsection{Nutrient Treatability Study}

To achieve maximum rates of biodegradation within a sediment and aquifer ecosystem, both inorganic nutrients and oxygen may be required as nutritional additives. Since each ecological habitat has different microbial consortia, the combination of inorganic nutrients necessary for maximum growth is specific for each site. A total of 34 combinations of inorganic nutrients were examined to determine which combination would give the maximum stimulation of the microbial population. Aliquots $(50 \mathrm{~mL})$ of the mixture of groundwater from three wells (CSD-4D, CSD-11D, and CSD-13D) were placed in 500-mL reaction vessels. The appropriate combinations of stock solutions of inorganic nutrients (Table 6) were added to each bottle, along with $50 \mu \mathrm{L}$ of diesel fuel to serve as the sole organic carbon source. Negative controls did not contain the diesel fuel. An additional $50 \mu \mathrm{L}$ of diesel fuel was added after the first week. At the end of the two-week incubation period, the vessels were acidified to dissolve any precipitates and to stop microbial growth, and the cell yield was gravimetrically determined.

\subsubsection{Nutrient Stability Tests}

Investigations were conducted to determine whether the introducing the most effective nutrient solution would affect the soil permeability. The interaction between the soil and nutrient solution was determined using columns packed with the site soil and treated consecutively with the groundwater, nutrient solution in groundwater, and an oxygen source (hydrogen peroxide). The nutrient stability tests were also used to determine the interaction between hydrogen peroxide and the soil.

\subsubsection{Blodegradability Studies}

Biodegradation studies determined the ability of the diesel contaminants to be removed biologically. Sediment samples were collected from boring CSD-13 (Figure 2) at 17 feet and used in the mineralization study of the diesel contaminants. The sediment samples were predominantly clay and contained approximately $432 \mathrm{ppm}$ of total petroleum hydrocarbon. The volatile fraction of diesel and dodecane 
was followed by headspace gas chromatography analyses using a Perkin-Elmer Model 8320 gas chromatograph equipped with a Model HS-6 headspace analyzer. These analyses were used to demonstrate a reduction in the overall concentration of diesel fuel.

Calibration curves for the total volatile fraction were prepared by peak area analyses. The concentration of dodecane was determined from the peak area matching the retention time of dodecane standards. Other compounds may have co-eluted with the dodecane and prevented an accurate determination of the dodecane concentration.

The four perturbation treatments for the biodegradation studies included the following:

- a nutrient-amended series

- an unamended series

- a nutrient-amended control series

- an unamended series.

A series of positive nutrient-amended controls and a series of unamended negative controls were included. Negative controls accounted for losses from the system other than those due to microbial activity. Two-hundred fifty grams of sediment from boring CSD-13 were placed in a large beaker and thoroughly mixed. Ten-gram aliquots of the sediment were placed in sterile, $70-\mathrm{mL}$ serum bottles for the TPH test series and 1-gram subsamples were placed in sterile, 9-mL vials for the volatile test series.

The first perturbation treatment was prepared with $100 \mathrm{~mL}$ of groundwater amended with $687 \mathrm{mg} / \mathrm{L}$ phosphate, 160 $\mathrm{mg} / \mathrm{L}$ potassium, $336 \mathrm{mg} / \mathrm{L}$ ammonia, $57 \mathrm{mg} / \mathrm{L}$ carbonate, $3.6 \mathrm{mg} / \mathrm{L}$ calcium, $19.5 \mathrm{mg} / \mathrm{L}$ magnesium, $4 \mathrm{mg} / \mathrm{L}$ manganese, $1 \mathrm{mg} / \mathrm{L}$ iron, $87 \mathrm{mg} / \mathrm{L}$ sulfate, $670 \mathrm{mg} / \mathrm{L}$ chloride, and $172 \mathrm{mg} / \mathrm{L}$ sodium. Ten milliliters of the groundwater nutrient solution were added to each serum bottle, in the TPH series and $1 \mathrm{~mL}$ into the volatile series. The second perturbation treatment received only groundwater, and the groundwater used in the third perturbation treatment was amended with the same combination of inorganic nutrients as the first series, but also received $4 \mathrm{~mL}$ of sulfuric acid, a poisoned control agent. The fourth perturbation treatment was prepared with $100 \mathrm{~mL}$ of groundwater and $4 \mathrm{~mL}$ of sulfuric acid. Each serum bottle was sealed with a sterile teflon-lined rubber septa and mixed with a vortex mixer. All of the serum bottles were incubated at $22^{\circ} \mathrm{C}$.

An additional biodegradation test was performed to determine whether the contaminated sediments could be treated with a vacuum system (i.e., providing the oxygen necessary for biodegradation of the diesel fuel while removing the volatile diesel fraction). A glass column was packed with 100 grams of contaminated sediment from CSD-13D. The sediment was periodically moistened with a nutrient amended groundwater as described in Table 6. A vacuum of $200 \mathrm{~mm} \mathrm{Hg}$ was placed on the bottom of the column and air was drawn through the column. Samples were removed periodically and analyzed for TPH as previously described.

\subsubsection{Two- and Three-Dimensional Visualization}

A two-dimensional contour mapping program MacGridzo (RockWare, Wheat Ridge, CO) for the Macintosh computer was used to prepare maps of the distribution of TPH concentration from discrete, 10-footthick sediment intervals. The plots are shown in Figures 6-9. These maps suggest that the TPH plume has moved in a southwesterly direction following the land surface topography. Because of the extensive clay deposits in the vadose zone, horizontal migration has greatly exceeded vertical migration. In fact, more than $80 \%$ of the contamination appears to be confined to the upper 20 feet of the soil column.

To better visualize the distribution of contamination, three-dimensional (3-D) images were prepared using a 3-D modeling software package (Interactive Volume Modeling ${ }^{\mathrm{NM}}$ [IVM], version 5.0, Dynamic Graphics, Alameda, CA). These models were created from irregularly spaced data values specified by $x, y$, and $z$ coordinates and a property value. Using a bicubic spline algorithm, the data values were transformed into a regularly spaced 3-D grid with a minimum tension gridding technique. Display files were created from the grid by specifying a series of concentration surfaces to be contoured. The display files were interactively viewed from numerous angles, layers, and sections were removed, and selected concentration zones were interpreted and analyzed.

The resulting 3-D grid files were used to create the displays shown in Figures 10-13. Surfaces were used to define the boundaries for the 3-D grids.

\subsection{Results and Discussion}

\subsection{Sediment Analyses}

The concentration of TPHs in individual soil and sediment samples is given in Table 2. Sediment borings in the fuel storage area (CSD-3D, $-4 \mathrm{D}$, and -5D) had an average of $256 \mathrm{ppm}$ in the 0-15-foot zone. Isolated zones showed contaminant concentrations of less than $160 \mathrm{ppm}$ in the 
sediments from 15 to 82 feet in CSD-4D. CSD-6D, located to the north of the diesel fuel storage area, had a concentration of $5040 \mathrm{ppm}$ at the 10-12-foot interval below land surface. Sediments from CSD-7D showed contamination above the detection limits only at 6 feet below land surface. CSD-8D appeared to be clean except for one sample at $41-43$ feet that showed a very low level of contamination. Contaminant levels above $100 \mathrm{ppm}$ were found in CSD-9D at depths down to 72 feet. Sediments from CSD-10D and CSD-12D did not show (PAHs) above detectable limits and appeared to be outside the plume of contamination. Sediments from CSD-11D and -13D revealed relatively high levels of contamination in the surface soils. CSD-11D did not show any contamination below 15 feet, but CSD-13D showed contamination extending to 57 feet. The contaminants found in CSD-9D, $-11 D$, and $-13 D$ indicated that the plume is quite extensive.

The TPH analysis revealed values from 4.1 to $5040 \mathrm{mg} / \mathrm{kg}$ of sediment. Analyses of groundwater collected with HydroPunch sampling demonstrated undetectable concentrations of TPH in the groundwater, even though sediment concentrations in the unsaturated zone were often high. The TPH analysis of sediments indicated that the absolute extent of contamination has not yet been determined on the western-most boundary of the area. However, because the highest TPH concentrations at the boundaries were just above detection limits and coincided with the calculated outer edge of the contamination, we believe that the zone of contamination has been adequately defined.

The monitoring wells have not shown detectable levels of dissolved hydrocarbons (Fliermans et al. 1993). Analysis of the groundwater for volatile organic compounds (VOCs) showed no VOCs at levels above the limit of detection $(<5-10 \mathrm{ppb})$ for the method. The field and trip blanks contained no VOCs except for methylene chloride, which was found in all samples, including the method blank, indicating that it is most likely laboratory contaminant.

\subsection{Two- and Three-Dimensional Visualization}

The TPH assessment program revealed widespread contamination of the soils and sediments. The majority of the contaminants was found between $0-15$ feet. Sediment borings to the east of the underground fuel storage area did not show detectable concentrations of TPH in the intervals that were sampled. Plume analyses, as depicted in Figures $10-13$, indicate that the plume is primarily associated with the top 15 feet of soil and sediments. Deep but small pockets of petroleum hydrocarbons were observed in CSD-9 and CSD-23 at depths of greater than 60 feet.

The results from the 3-D imaging data are shown in Figures 10-13 and indicate that the bulk of the contamination lies in a region that corresponds to a low spot in the terrain and may represent a sink for the TPH. The TPH distribution suggests that very little extends beyond the area already investigated. The hydrology, geology, topography, and nature of the contaminant suggest that the diesel fuel contaminating the sediments in this area is moving very slowly or not at all and has not impacted the groundwater in the area.

\subsection{Bacteriological Analyses}

Bacterial densities in the soils and sediments were generally quite low (Fliermans et al. 1993). Most of the samples contained fewer than 100 CFUs per gram of sediments for the total bacterial counts and 200 CFUs per gram of sediments for the hydrocarbon-utilizing bacteria. These limits of detection represent the minimum number of microorganisms that can be counted by the procedures used in the tests. In the surface soils from 0 to 15 feet, elevated total microbial counts were found for borings $3,4,5$, and 6 , which are in the vicinity of the tank storage area. However, only boring 5 had elevated hydrocarbon-utilizing bacterial counts. Elevated bacterial counts were found in only a few instances in sediment samples deeper than 15 feet, although boring 10 had elevated counts in the 45 to 60 foot range.

The groundwater bacterial counts were somewhat higher than the sediments for two of the three wells (Fliermans et al. 1993). Total plate counts ranged from $3.6 \times 10^{3}$ to $4.4 \times$ $10^{4}$, while hydrocarbon utilizers ranged from $4.2 \times 10^{3}$ to $1.48 \times 10^{4}$ per $\mathrm{mL}$. Aseptic control conditions were maintained during processing and shipping of samples as shown by the field and trip control blanks ranging from $10-20 \mathrm{CFU} / \mathrm{mL}$ of sample. Mineral medium plates spread with $0.1 \mathrm{~mL}$ of groundwater but not incubated under diesel vapors contained an average of 90 organisms per $\mathrm{mL}$. The data showed that greater densities of the acclimated microbiological population was achieved in diesel vapors.

Direct bacterial counts (AODC) showed higher densities than those found for viable plate counts. In some cases, such as CSD-4D, no viable plate counts were recorded, demonstrating that although there may be organisms present in the groundwater, they are unable to grow on the media used for the viable enumerations. 


\subsection{Nutrient Treatability Study}

The nutrient stimulation investigations demonstrated the presence of microbial populations capable of degrading the diesel contamination. The data in Table 7 show the cell yields for the nutrient study. Cell yields of greater than 15 times background were obtained during the nutrient optimization study when the systems were supplied with the necessary inorganic nutrients. Minimal growth was achieved in the system without additional inorganic nutrients (test 2), while the additions of both ammonia and phosphate increased cell yields by 5-6 fold (tests 5 and 6). The greatest cell yield (nearly 16 fold) occurred in test 27 , which received all of the inorganic nutrients except carbonate. The second highest yield, test 28 , contained ammonia, phosphate, carbonate, magnesium, manganese, and iron, while the third highest yield was for test 9 and contained magnesium in addition to ammonia and phosphate. The tests with the best yields appeared to contain ammonia, phosphate, and magnesium and generally manganese and iron.

Bacterial cell biomass used up to $23 \%$ of the added diesel fuel, with much of the remaining fuel being converted to carbon dioxide and water. Growth occurred with the groundwater microbial consortia using the added diesel as the sole carbon and energy source, even though there was no apparent diesel contamination in the groundwater samples. Such data demonstrates that the indigenous microorganisms from both the sediments and groundwater can acclimate to biodegrade the diesel when supplied with the necessary oxygen and inorganic nutrients.

During the nutrient-amended treatments, biodegradation studies of the volatile fraction of diesel fuel indicated that this fraction was reduced by $67 \%$ within 35 days when the sediments and groundwater samples were supplemented with the necessary inorganic nutrients (Figure 14). Treatment \#2-UT, which did not receive any nutrients, showed that total VOCs were reduced only $18 \%$. The data indicated that adding inorganic nutrients enhanced the biological removal of the volatile fraction of the diesel fuel over adding oxygen. There was no reduction in the volatile fraction in the nutrient-amended controls (treatment \#3$A C)$ or unamended controls (treatment \#4-UC), although there was some variability in the measured concentrations of volatiles. Phosphate may sorb to the soil and not be available for the microorganisms. While adding nutrient solution may enhance diesel fuel degradation, reaction with the minerals in the groundwater (particularly iron, magnesium, and calcium) may cause a precipitate to form.
Excessive precipitation of the nutrient solution will likely clog the soil pores, resulting in a decrease in the soil permeability and formation blockage.

To enhance TPH oxidation, additional oxygen sources are often provided. One such source is hydrogen peroxide, which decomposes water and oxygen. Hydrogen peroxide provides a much greater quantity of oxygen to the subsurface than air, or compressed or liquid oxygen, which are other common methods of oxygen addition. Experiments were conducted to determine the rate of hydrogen peroxide decomposition in CSDSF sediments. If the hydrogen peroxide decomposed rapidly, the subsurface environment may require treatment with phosphate or other agents to stabilize the decomposition rate before hydrogen peroxide can be introduced. Additionally, phosphate may sorb to the soil particles and become unavailable to the microbial population. On the other hand, if the hydrogen peroxide is readily decomposed in the formation, then the rate of oxygen production may be too slow to support maximal aerobic microbial growth. Thus a nutrient balance with oxygenation is sought.

The results of the phosphate sorption and hydrogen-peroxide stability test are expressed in Table 8. Two sediment samples with high TPH concentrations were used in the test. The first test used 20 grams of sediment collected from borehole CSD-13D at a depth interval of 5-7 feet along with $100 \mathrm{~mL}$ of groundwater spiked with $81 \mathrm{ppm}$ phosphate and $150 \mathrm{ppm}$ hydrogen peroxide. The second test employed sediment from boring CSD-6D at a depth interval of 10-12 feet along with $100 \mathrm{~mL}$ of groundwater amended with $280 \mathrm{mg} / \mathrm{L}$ of phosphate and $265 \mathrm{mg} / \mathrm{L}$ of hydrogen peroxide. Samples were taken periodically from the liquid above the sediment, centrifuged to separate sediments from groundwater, and checked for the remaining concentrations of phosphate and hydrogen peroxide. Phosphate was measured colorimetrically with ammonium molybdate and ascorbic acid. Hydrogen-peroxide concentrations were determined colorimetrically with titanium sulfate.

Phosphate sorption to the CSD-13D sediment sample was relatively rapid (Table 8) in that the phosphate levels were reduced by more than half within 2 hours and by $90 \%$ after 5 hours. When additional phosphate was added, the concentration in solution was reduced by $30 \%$ within 4 hours and by $67 \%$ within the next 20 hours. The phosphate demand for this sediment was high at approximately 2.3 pounds per cubic yard. The sample from CSD-6D showed 
less phosphate adsorption (Table 8), in that the phosphate concentration was reduced by $50 \%$ after 8 hours. The phosphate sorption for this sample amounted to 1.7 pounds per cubic yard.

The hydrogen peroxide concentrations dropped rapidly from $150 \mathrm{mg} / \mathrm{L}$ down to $9 \mathrm{mg} / \mathrm{L}$ within 21 hours in the sediment sample from CSD-13D (Table 8). A similar rate of hydrogen peroxide breakdown was observed after adding more hydrogen peroxide and phosphate to the soil and groundwater solution. The stability of the hydrogen peroxide in the CSD-6D sample was improved in that the concentration of hydrogen peroxide decreased by just over $25 \%$ within 8 hours (Table 8 ). Based on the stability of the peroxide, it appears that for these particular sediments hydrogen peroxide can be used as the oxygen source if the phosphate demand were satisfied and the other site conditions were favorable for the use of in situ bioreclamation.

Column sediment tests were established to determine the affect of the nutrient amendments on the infiltration rate. These data are given in Table 9. Two columns were prepared-one with $\mathbf{4 0}$ grams of a sediment from soil boring CSD-6D at a depth of 10-12 feet, and the second with 40 grams of a sediment from boring CSD-13D at a depth of 5-7 feet. The columns were moistened with $200 \mathrm{~mL}$ of groundwater, and the time was recorded for $50 \mathrm{~mL}$ of the groundwater plus amendments to pass through the column. Reasonable rates of infiltration were achieved initially in both columns for the passage of groundwater (i.e., $13 \mathrm{~mL} / \mathrm{min}$ for CSD-13D sediments and $18 \mathrm{~mL} / \mathrm{min}$ for CSD-6D sediments [Table 9]). However, the sediments plugged when inorganic nutrients were added. The addition of hydrogen peroxide resulted in decreased flow for both columns. Sediments from CSD-13D became fully plugged, and the flow through the CSD-6D column was reduced to $1 \mathrm{~mL} / \mathrm{min}$. The high clay content of the sediment samples seemed to prevent nutrient addjtions since CSD-13D consisted of sand with clay and silt with an estimated $25 \%$ clay and $15 \%$ silt. The sample from CSD-6D consisted of cohesive, medium plasticity clay with approximately $15 \%$ sand.

\subsection{Biodegradability Studies}

Experiments were also conducted to demonstrate the biotransformation and complete mineralization of dodecane, one of the components of diesel fuel, to carbon dioxide and water. Mineralization studies were conducted with soils from CSD-13D at a depth of 2-4 feet and with sediments from depths of 6-19 feet. Dodecane biotransformation experiments were also conducted with sediments from CSD-13D at a depth of 17 feet. Up to $4.4 \%$ of the added carbon-14 label was mineralized in the soil from CSD-13D (2-4 feet) when amended with 80 ppm phosphate and $50 \mathrm{ppm}$ ammonia. Some mineralization of dodecane occurred with addition of phosphate by itself, but not for ammonia alone. No more than $7.6 \%$ of the label was mineralized in these studies. The high concentrations of other biodegradable contaminants and the location of the carbon-14 label on only the first carbon of dodecane contributed to the apparent low percentage conversion of the dodecane to carbon dioxide.

In the biotransformation experiment, $80 \%$ of the dodecane was removed in 35 days when the soils were amended with ammonia, phosphate, and other inorganic nutrients and incubated under aerobic conditions. Without any additional nutrients, $69 \%$ of the dodecane were biotransformed. Approximately $50 \%$ of the dodecane was lost in the nutrient-amended and unamended controls. These losses may be a result of interaction between the acid used as a biological inhibitor and the dodecane. The following may have contributed to the higher percentage of dodecane removal in the biotransformation experiment than seen in the mineralization experiment:

1. The biotransformation experiment only followed the loss of the parent compound and not complete conversion to carbon dioxide.

2. The headspace quantification method may be subject to interferences with compounds that have similar retention times to that of dodecane.

3. The biotransformation experiment was carried out for a longer period.

4. The mineralization experiments were carried out with dodecane, which was only labeled on the first carbon.

The TPH levels were reduced from $467 \mathrm{ppm}$ down to 70 ppm after 24 days (Figure 16). Some removal was probably resulted from volatilization of the lighter fraction of diesel. While this technique was successful in the laboratory, it may be difficult to apply in the field. The clayey soils found throughout much of the CSDSF site will make it difficult to draw the nutrients and air through the contaminated zone. 


\subsection{Conclusions and Recommendations}

The hydrology, geology, topography, and the nature of the contaminant suggest that the diesel fuel contaminating the sediments in this area is moving very slowly or not at all. Additionally, impacts to the groundwater have not been observed. Small areas of perched water found at depths of approximately 25 feet below ground surface were overlying a low permeability sandy clay unit of limited extent. The static water table across the site is between 238 to 244 feet mean sea level (approximately 45 to 75 feet below ground surface) as shown in Figure 5. Directions of groundwater flow vary depending on location; however, the dominant direction is to the west in the direction of the lowest topographical elevation (Figure 5).

In situ bioreclamation was chosen as one of the remediation alternatives for further investigation, since bioremediation is effective in degrading TPHs. Conventional treatment relies on liquid additions circulating through the contaminated soils via horizontal or injection wells, infiltration galleries, and withdrawal wells to supply the necessary nutrients to the subsurface environments. To determine if in situ bioreclamation was an appropriate cleanup technology for this site soil, sediment and groundwater samples were collected for laboratory analyses. The studies involved determining the microbial distribution of both the total bacterial and hydrocarbon-utilizing populations, the nutrient requirements for maximum growth rate, the rate and extent of biodegradation of the organic contaminants, and compatibility of the nutrient mixture with the subsurface soils.

The Bioreclamation Feasibility Assessment Study revealed that indigenous microorganisms that degrade diesel fuel were present in the soil and sediments at the Central Shop Diesel Storage Facility site. A nutrient mix to stimulate the indigenous microorganisms was tested on sediment core samples, and optimum concentrations were established to yield the most microbial cells.

Problems arose when the inorganic nutrients and oxygen were added to the Central Shops Diesel Storage Facility soils and sediments. There is a relatively high phosphate demand by the soils, ranging from 1.7 pounds to 2.3 pounds per cubic yard, which must be met before an oxygen source such as hydrogen peroxide can be added to the soil without creating plugging problems. The rate of hydrogen peroxide decomposition in the presence of the soils was reasonable. When nutrients are added to the groundwater, they appear to release fines from the soil, which plug the formation. Even with pretreating the soils with the nutrient solution, groundwater flow through the soil columns was restricted when hydrogen peroxide was added.

However, soil column studies suggested that injecting this nutrient mix would plug the soil, through microbial biomass and/or inorganic precipitates from chemical reactions. This formation plugging seriously limits using conventional liquid nutrient infiltration galleries to enhance indigenous microbial populations in these soils. The location of most of the diesel contaminants in the unsaturated soil above the groundwater table, the relatively low permeability of the soils, and the problems with adding hydrogen peroxide and nutrients to the soils will probably preclude using conventional in situ bioreclamation for the site. Thus, conventional in situ biodegradation through injection of liquid nutrients via infiltration galleries may not be appropriate. However, if plume containment was desirable, these studies indicated that biomass plugging of the soil could inhibit subsurface water flow and may be appropriate as a method of containment.

The investigation that allowed the removal of the total petroleum hydrocarbon by vacuum extraction and enhanced biodegradation through bioventing indicated that this method may be useful. It will probably not be difficult to draw the necessary oxygen and nitrogen through the clayey soils using pressurized air. The nitrogen present in the compressed air will serve as a nutrient source for the microbial consortia present in the soils. Field-scale demonstrations of the vacuum-extraction, enhanced-bioventing biodegradation processes have been accomplished for TCE-contaminated soils at $M$ Area and are expected to be work favorably at the Central Shops Diesel Storage Facility (Eddy et al., 1991; Looney et al., 1991).

The most economical and technically feasible option to clean up the diesel contaminated soil at the Central Shops Diesel Storage Facility can be approached in two ways. Initially, small vertical injection and vacuum extraction wells would be inserted into the most contaminated and shallowest areas of the plume to biovent and bioremediate the plume. This would allow the bioremediation of the greatest concentration of the TPHs with the least cost. Since the contamination has not entered the groundwater, an immediate bioventing procedure would enhance the degradation without excavation. This phase of the bioremediation may well continue for 12-18 months followed by an evaluation of the residual plume. Core samples would be collected for comparison of the bioremediated plume with the initial conditions. 
Since these studies indicated that the CSDSF site may not be suitable for some conventional types of in situ bioremediation, a second approach is to excavate the shallow contaminated soils and treat them. A prepared bed treatment facility (soils facility) for all oil-contaminated soils at SRS has been constructed at D Area. Because the majority of contamination at CSDSF is shallow, much of the contaminated soil from the Central Shops Diesel Storage Facility would be excavated and treated in this facility. The excavated material would be mixed with nutrients at the controlled site (soils facility) and brought to acceptable levels of TPH by the indigenous microflora in a rapid and costeffective manner. The facility is used to treat all petroleum-contaminated surface soil at SRS now and in the future. The clayey nature of much of the sediments will not restrict land farming because the nutrients can be added directly to soils and mixed manually. Whereas the bulk of the contaminated soils is confined to a narrow and shallow depth ( $<20 \mathrm{ft}$ ), removing the highly contaminated material may be the most effective remediation of the site. Microbial populations that are acclimated to the diesel contaminants or can become acclimated to diesel once the proper inorganic nutrients are available are present at the contaminated site.

The small pools of deeper contamination ( $>30$ feet) will require more innovative treatment (e.g., bioventing). Bioremediation would be achieved by placing vertical wells into the most heavily contaminated area. Vacuum extraction could remove the volatile portion of the TPH and also establish a bioventing regime where the indigenous microbial populations would be stimulated to degrade the TPHs in situ.

Since this plume has probably existed for more than 20 years at this site and there is no evidence of immediate danger to groundwater supplies in the area, we propose using this site to test innovative technologies, for in situ bioremediation. These studies could significantly improve our ability to cleanup similar sites by decreasing remediation time and costs and improving terminal destruction of the contaminants with minimal environmental disturbance.

\subsection{References}

Abelson, P., 1989, “Cleaning Hazardous Waste Sites", Science 246:1097.

Amador, Alphons and A. C. Uijtewaal, 1992, "Buried Pesticide Waste Hazard to Poland", Waste Management \& Research 10: 387-398.

Eddy, C. A., B. B. Looney, J. M. Dougherty, T. C. Hazen, and D. S. Kaback, 1991, Characterization of the Geology, Geochemistry, Hydrology and Microbiology of the In Situ Air Stripping Demonstration Site at the Savannah River Site. WSRC-RP-93-0369, Westinghouse Savannah River Company, Aiken, SC 29808.

Fliermans, C. B., H. W. Bledsoe, and T. C. Hazen, 1993,. Characterization and Reclamation Assessment for the Central Shops Diesel Storage Facility, Savannah River Site, Aiken, SC, WSRC-MS-93-039, Westinghouse Savannah River Company, Aiken, SC 29808.

Hazen, T. C., 1991, Test Plan for In Situ Bioremediation Demonstration of the Savannah River Integrated Demonstration Project, DOE/OTD TTP No.: SR 0566-01.

Looney, B. B., V. Price, D. J. Masdea, and C. A. Boe, 1988, Soil Gas and Soil Plug Survey at the Central Shops Diesel Storage Facility (8318)., DPST-88-829. E. I. duPont de Nemours \& Co. Savannah River Laboratory, Aiken, SC 29808.

Looney, B. B., T. C. Hazen, D. S. Kaback, and C. A. Eddy, 1991, Full Scale Field Test of the In Situ Air Stripping Process at the Savannah River Integrated Demonstration Test Site, WSRC-RD-91-22, Westinghouse Savannah River Company, Aiken, SC 29808.

Manchon, Bruce, 1992, "Cone Penetrometer Testing, Hydropunch ${ }^{8}$, and Borehole Geophysics Applications for Environmental Investigations", Journal of Soil Contamination, 1(4):321-338.

Phelps, T. J., C. B. Fliermans, T. Garland, S. M. Pfiffner, and D. C White, 1989, "Recovery of Deep Subsurface Material for Microbiological Studies," Journal of Microbiological Methods 9: 267-279.

Sargent, K. A. and C. B. Fliermans, 1989, "Microbiology and Geological Comparisons of the Terrestrial Deep Subsurface", Geomicrobiology Journal 7: 1-11. 
Table 1. Grain-size Distribution for Sediments Collected at Selected Intervals at the CSDSF Site (expressed in percent)

\begin{tabular}{ccccc} 
Depth (ft) & $\begin{array}{c}\text { \% Coarse } \\
\text { Sonds }\end{array}$ & $\begin{array}{c}\text { \% Medium } \\
\text { Sands }\end{array}$ & \% Fine Sands & $\begin{array}{c}\text { \% Very Fine } \\
\text { Sands }\end{array}$ \\
\hline $62-64$ & 30 & 50 & 20 & 0 \\
$66-67$ & 5 & 27 & 0 & 68 \\
$67-68$ & 15 & 52 & 0 & 33
\end{tabular}

Table 2. Concentration of Petroleum Hydrocarbons at Depth

\begin{tabular}{|c|c|c|c|c|c|}
\hline Well & All Depths & $0-19 \mathrm{n}$ & $20-39 \mathrm{nt}$ & $40-59 \mathrm{ft}$ & $>60 \mathrm{ft}$ \\
\hline CSD-1D & 50 & 0 & 0 & 50 & 0 \\
\hline CSD-2D & 50 & 0 & 50 & 50 & 0 \\
\hline CSD-3D & 665 & 665 & 0 & 0 & 0 \\
\hline CSD-4D & 887 & 887 & 156 & 50 & 87 \\
\hline CSD-5D & 603 & 603 & 0 & 0 & 0 \\
\hline CSD-6D & 5040 & 5040 & 0 & 0 & 0 \\
\hline CSD-7D & 273 & 273 & 0 & 0 & 0 \\
\hline CSD-8D & 57 & 0 & 50 & 57 & 50 \\
\hline CSD-9D & 384 & 383 & 265 & 269 & 384 \\
\hline CSD-10D & 50 & 0 & 50 & 50 & 50 \\
\hline CSD-11D & 2413 & 2413 & 50 & 50 & 50 \\
\hline CSD-12D & 50 & 0 & 50 & 50 & 50 \\
\hline CSD-13D & 4377 & 4377 & 492 & 94 & 50 \\
\hline CSD-15D & 85 & 85 & 4.7 & 4.7 & 4.8 \\
\hline CSD-16D & 6.7 & 5.8 & 6.7 & 4.7 & 4.8 \\
\hline CSD-17D & 1700 & 1700 & 8.2 & 4.7 & 6.1 \\
\hline CSD-18D & 34 & 11 & 34 & 8.5 & 0 \\
\hline CSD-19D & 69 & 69 & 7.1 & 4.8 & 0 \\
\hline CSD-20D & 65 & 65 & 7.5 & 4.9 & 0 \\
\hline CSD-21D & 1000 & 1000 & 58 & 14 & 0 \\
\hline CSD-22D & 1500 & 1500 & 43 & 89 & 0 \\
\hline CSD-23D & 2600 & 2600 & 510 & 110 & 0 \\
\hline CSD-24D & 5.1 & 5.1 & 4.8 & 4.8 & 0 \\
\hline CSD-25D & 5 & 4.9 & 5 & 4.9 & 0 \\
\hline CSD-26D & 840 & 840 & 5 & 4.9 & 0 \\
\hline CSD-27D & 230 & 230 & 5.5 & 5 & 0 \\
\hline CSD-28D & 32 & 32 & 5.1 & 5.1 & 0 \\
\hline CSD-29D & 170 & 170 & 4.9 & 5 & 0 \\
\hline Maximum & & 5040 & & & \\
\hline Minimum & & 4.1 & & & \\
\hline
\end{tabular}


Table 3. Concentration of Lead at Depth in the Sediments of Central Shops Diesel Storage Facility

\begin{tabular}{|c|c|c|c|}
\hline Well ID & Depth (ft) & Concentration & Detection Limit \\
\hline CS-15D & $3-5$ & $5.7 \mathrm{mg} / \mathrm{Kg}$ & 0.68 \\
\hline CS-15D & $8-10$ & $3.8 \mathrm{mg} / \mathrm{Kg}$ & 0.71 \\
\hline CS-15D & $13-15$ & $20.9 \mathrm{mg} / \mathrm{Kg}$ & 2.90 \\
\hline CS-15D & $18-20$ & $19.3 \mathrm{mg} / \mathrm{Kg}$ & 2.80 \\
\hline CS-15D & $23-25$ & $7.7 \mathrm{mg} / \mathrm{Kg}$ & 0.68 \\
\hline CS-15D & $28-30$ & $5.0 \mathrm{mg} / \mathrm{Kg}$ & 0.67 \\
\hline CS-15D & $33-35$ & $4.6 \mathrm{mg} / \mathrm{Kg}$ & 0.68 \\
\hline CS-15D & $38-40$ & $15.5 \mathrm{mg} / \mathrm{Kg}$ & 2.80 \\
\hline CS-15D & $43-45$ & $5.0 \mathrm{mg} / \mathrm{Kg}$ & 0.74 \\
\hline CS-15D & $48-50$ & $5.8 \mathrm{mg} / \mathrm{Kg}$ & 0.73 \\
\hline CS-15D & $53-55$ & $8.9 \mathrm{mg} / \mathrm{Kg}$ & 0.72 \\
\hline CS-15D & $58-60$ & $9.2 \mathrm{mg} / \mathrm{Kg}$ & 0.69 \\
\hline CS-15D & $63-65$ & $4.0 \mathrm{mg} / \mathrm{Kg}$ & 0.67 \\
\hline CS-15D & $68-70$ & $4.7 \mathrm{mg} / \mathrm{Kg}$ & 0.65 \\
\hline CS-15D & $73-75$ & $3.8 \mathrm{mg} / \mathrm{Kg}$ & 0.70 \\
\hline CS-15D & $78-80$ & $2.1 \mathrm{mg} / \mathrm{Kg}$ & 0.71 \\
\hline CS-16D & $3-5$ & $17.5 \mathrm{mg} / \mathrm{Kg}$ & 2.90 \\
\hline CS-16D & $8-10$ & $3.2 \mathrm{mg} / \mathrm{Kg}$ & 0.69 \\
\hline CS-16D & $13-15$ & $9.7 \mathrm{mg} / \mathrm{Kg}$ & 0.72 \\
\hline CS-16D & $18-20$ & $10.2 \mathrm{mg} / \mathrm{Kg}$ & 0.72 \\
\hline CS-16D & $23-25$ & $11.1 \mathrm{mg} / \mathrm{Kg}$ & 0.72 \\
\hline CS-16D & $28-30$ & $3.3 \mathrm{mg} / \mathrm{Kg}$ & 0.66 \\
\hline CS-16D & $33-35$ & $7.4 \mathrm{mg} / \mathrm{Kg}$ & 0.69 \\
\hline$C S-16 D$ & 38,40 & $5.6 \mathrm{mg} / \mathrm{Kg}$ & 0.70 \\
\hline CS-16D & $43-45$ & $6.7 \mathrm{mg} / \mathrm{Kg}$ & 0.71 \\
\hline CS-16D & $48-50$ & $3.1 \mathrm{mg} / \mathrm{Kg}$ & 0.68 \\
\hline CS-16D & $53-55$ & $4.3 \mathrm{mg} / \mathrm{Kg}$ & 0.67 \\
\hline CS-16D & $58-60$ & $2.2 \mathrm{mg} / \mathrm{Kg}$ & 0.66 \\
\hline CS-16D & $63-65$ & $1.6 \mathrm{mg} / \mathrm{Kg}$ & 0.69 \\
\hline CS-16D & $68-70$ & $3.2 \mathrm{mg} / \mathrm{Kg}$ & 0.73 \\
\hline CS-17D & $3-5$ & $6.1 \mathrm{mg} / \mathrm{Kg}$ & 0.68 \\
\hline CS-17D & $8-10$ & $4.2 \mathrm{mg} / \mathrm{Kg}$ & 0.72 \\
\hline$C S-17 D$ & $13-15$ & $6.3 \mathrm{mg} / \mathrm{Kg}$ & 0.72 \\
\hline CS-17D & $18-20$ & $8.4 \mathrm{mg} / \mathrm{Kg}$ & 0.70 \\
\hline$C S-17 D$ & $23-25$ & $5.5 \mathrm{mg} / \mathrm{Kg}$ & 0.68 \\
\hline
\end{tabular}


WSRC-TR-94-0344

Table 3. Concentration of Lead at Depth in the Sediments of Central Shops Diesel Storage Facility (Contd)

\begin{tabular}{|c|c|c|c|}
\hline Well ID & Depth (II) & Concentration & Detection Limit \\
\hline CS-17D & $28-30$ & $29 \mathrm{mg} / \mathrm{Kg}$ & 0.71 \\
\hline CS-17D & $33-35$ & $3.1 \mathrm{mg} / \mathrm{Kg}$ & 0.68 \\
\hline CS-17D & $38-40$ & $2.9 \mathrm{mg} / \mathrm{Kg}$ & 0.71 \\
\hline CS-17D & $43-45$ & $12.8 \mathrm{mg} / \mathrm{Kg}$ & 1.40 \\
\hline CS-17D & $48-50$ & $5.4 \mathrm{mg} / \mathrm{Kg}$ & 0.67 \\
\hline CS-17D & $53-55$ & $4.6 \mathrm{mg} / \mathrm{Kg}$ & 0.73 \\
\hline CS-17D & $58-60$ & $2.8 \mathrm{mg} / \mathrm{Kg}$ & 0.71 \\
\hline$C S-17 D$ & $63-65$ & $136 \mathrm{mg} / \mathrm{Kg}$ & 14.2 \\
\hline CS-17D & $68-70$ & $4.7 \mathrm{mg} / \mathrm{Kg}$ & 0.71 \\
\hline$C S-17 D$ & $73-75$ & $4.2 \mathrm{mg} / \mathrm{Kg}$ & 0.72 \\
\hline CS-17D & $78-80$ & $2.1 \mathrm{mg} / \mathrm{Kg}$ & 0.69 \\
\hline CS-17D & $83-85$ & $4.9 \mathrm{mg} / \mathrm{Kg}$ & 0.72 \\
\hline CS-17D & $88-90$ & $5.8 \mathrm{mg} / \mathrm{Kg}$ & 0.71 \\
\hline CS-18D & $3-5$ & $6.5 \mathrm{mg} / \mathrm{Kg}$ & 0.67 \\
\hline CS-18D & $8-10$ & $9.3 \mathrm{mg} / \mathrm{Kg}$ & 0.66 \\
\hline CS-18D & $13-15$ & $8.9 \mathrm{mg} / \mathrm{Kg}$ & 0.71 \\
\hline CS-18D & $18-20$ & $5.9 \mathrm{mg} / \mathrm{Kg}$ & 0.70 \\
\hline CS-18D & $23-25$ & $5.6 \mathrm{mg} / \mathrm{Kg}$ & 0.69 \\
\hline CS-18D & $28-30$ & $6.6 \mathrm{mg} / \mathrm{Kg}$ & 0.65 \\
\hline CS-18D & $33-35$ & $5.3 \mathrm{mg} / \mathrm{Kg}$ & 0.66 \\
\hline CS-18D & $38-40$ & $3.6 \mathrm{mg} / \mathrm{Kg}$ & 0.68 \\
\hline CS-18D & $43-45$ & $1.4 \mathrm{mg} / \mathrm{Kg}$ & 0.65 \\
\hline CS-18D & $48-50$ & $3.0 \mathrm{mg} / \mathrm{Kg}$ & 0.71 \\
\hline CS-18D & $53-55$ & $3.1 \mathrm{Mg} / \mathrm{Kg}$ & 0.62 \\
\hline CS-19D & $3-5$ & $7.4 \mathrm{mg} / \mathrm{Kg}$ & 0.71 \\
\hline CS-19D & $8-10$ & $6.4 \mathrm{mg} / \mathrm{Kg}$ & 0.69 \\
\hline CS-19D & $13-15$ & $10.8 \mathrm{mg} / \mathrm{Kg}$ & 0.74 \\
\hline CS-19D & $18-20$ & $10.0 \mathrm{mg} / \mathrm{Kg}$ & 0.72 \\
\hline CS-19D & $23-25$ & $7.2 \mathrm{mg} / \mathrm{Kg}$ & 0.67 \\
\hline CS-19D & $28-30$ & $16.2 \mathrm{mg} / \mathrm{Kg}$ & 1.30 \\
\hline CS-19D & $33-35$ & $4.2 \mathrm{mg} / \mathrm{Kg}$ & 0.64 \\
\hline$C S-19 D$ & $38-40$ & $4.4 \mathrm{mg} / \mathrm{Kg}$ & 0.68 \\
\hline CS-19D & $43-45$ & $4.0 \mathrm{mg} / \mathrm{Kg}$ & 0.68 \\
\hline CS-19D & $48-50$ & $6.3 \mathrm{mg} / \mathrm{Kg}$ & 0.67 \\
\hline CS-19D & $53-55$ & $2.7 \mathrm{mg} / \mathrm{Kg}$ & 0.71 \\
\hline CS.20D & $3-5$ & $5.2 \mathrm{mg} / \mathrm{Kg}$ & 0.71 \\
\hline
\end{tabular}


Characterization and Reclamation for the Central Shops Diesel Storage Facility at the Savannah River Site

Table 3. Concentration of Lead at Depth in the Sediments of Central Shops Diesel Storage Facility (Contd)

\begin{tabular}{|c|c|c|c|}
\hline Well ID & Depth (ft) & Concentration & Detection Limit \\
\hline CS-20D & $8-10$ & $4.6 \mathrm{mg} / \mathrm{Kg}$ & 0.71 \\
\hline CS-20D & $13-15$ & $5.3 \mathrm{mg} / \mathrm{Kg}$ & 0.72 \\
\hline CS-20D & $18-20$ & $4.6 \mathrm{mg} / \mathrm{Kg}$ & 0.68 \\
\hline CS.20D & $23-25$ & $8.3 \mathrm{mg} / \mathrm{Kg}$ & 0.68 \\
\hline CS-20D & $28-30$ & $6.4 \mathrm{mg} / \mathrm{Kg}$ & 0.69 \\
\hline CS-20D & $33-35$ & $4.6 \mathrm{mg} / \mathrm{Kg}$ & 0.68 \\
\hline CS-20D & $38-40$ & $5.0 \mathrm{mg} / \mathrm{Kg}$ & 0.68 \\
\hline CS-20D & $43-45$ & $6.0 \mathrm{mg} / \mathrm{Kg}$ & 0.68 \\
\hline CS-20D & $48-50$ & $5.5 \mathrm{mg} / \mathrm{Kg}$ & 0.69 \\
\hline CS-20D & $53-55$ & $2.7 \mathrm{mg} / \mathrm{Kg}$ & 0.73 \\
\hline CS-21D & $3-5$ & $7.1 \mathrm{mg} / \mathrm{Kg}$ & 0.67 \\
\hline CS-21D & $8-10$ & $10.4 \mathrm{mg} / \mathrm{Kg}$ & 0.74 \\
\hline CS-21D & $13-15$ & $6.2 \mathrm{mg} / \mathrm{Kg}$ & 0.71 \\
\hline CS-21D & $18-20$ & $5.4 \mathrm{mg} / \mathrm{Kg}$ & 0.71 \\
\hline CS-21D & $23-25$ & $10.1 \mathrm{mg} / \mathrm{Kg}$ & 0.70 \\
\hline CS-21D & $28-30$ & $30.9 \mathrm{mg} / \mathrm{Kg}$ & 6.80 \\
\hline CS-21D & $33-35$ & $8.2 \mathrm{mg} / \mathrm{Kg}$ & 0.69 \\
\hline CS-21D & $38-40$ & $4.0 \mathrm{mg} / \mathrm{Kg}$ & 0.66 \\
\hline CS-21D & $43-45$ & $6.3 \mathrm{mg} / \mathrm{Kg}$ & 0.69 \\
\hline CS-21D & $48-50$ & $5.1 \mathrm{mg} / \mathrm{Kg}$ & 0.71 \\
\hline CS-21D & $53-55$ & $4.5 \mathrm{mg} / \mathrm{Kg}$ & 0.73 \\
\hline CS-21D & $58-60$ & $4.8 \mathrm{mg} / \mathrm{Kg}$ & 0.73 \\
\hline$C S-22 D$ & $3-5$ & $7.1 \mathrm{mg} / \mathrm{Kg}$ & 0.71 \\
\hline CS-22D & $6-8$ & $9.7 \mathrm{mg} / \mathrm{Kg}$ & 1.60 \\
\hline CS-22D & $9>11$ & $5.0 \mathrm{mg} / \mathrm{Kg}$ & 1.40 \\
\hline CS-22D & $12-14$ & $7.0 \mathrm{mg} / \mathrm{Kg}$ & 1.40 \\
\hline$C S-22 D$ & $15-17$ & $15.0 \mathrm{mg} / \mathrm{Kg}$ & 1.40 \\
\hline$C S-22 D$ & $18-20$ & $10.2 \mathrm{mg} / \mathrm{Kg}$ & 1.50 \\
\hline CS-22D & $21-23$ & $12.3 \mathrm{mg} / \mathrm{Kg}$ & 1.40 \\
\hline CS-22D & $28-30$ & $5.5 \mathrm{mg} / \mathrm{Kg}$ & 1.40 \\
\hline CS-22D & $33-35$ & $11.1 \mathrm{mg} / \mathrm{Kg}$ & 1.40 \\
\hline CS-22D & $38-40$ & $7.1 \mathrm{mg} / \mathrm{Kg}$ & 1.40 \\
\hline CS-22D & $43-45$ & $4.3 \mathrm{mg} / \mathrm{Kg}$ & 1.40 \\
\hline CS-23D & $3-5$ & $4.0 \mathrm{mg} / \mathrm{Kg}$ & 0.67 \\
\hline CS-23D & $8-10$ & $9.1 \mathrm{mg} / \mathrm{Kg}$. & 0.71 \\
\hline CS-23D & $13-15$ & $13.1 \mathrm{mg} / \mathrm{Kg}$ & 1.40 \\
\hline
\end{tabular}


WSRC-TR-94-0344

Table 3. Concentration of Lead at Depth in the Sediments of Central Shops Diesel Storage Facility (Contd)

\begin{tabular}{|c|c|c|c|}
\hline Well ID & Depth (ft) & Concentration & Detection Limit \\
\hline CS-23D & $18-20$ & $6.2 \mathrm{mg} / \mathrm{Kg}$ & 0.70 \\
\hline CS-23D & $23-25$ & $5.4 \mathrm{mg} / \mathrm{Kg}$ & 0.70 \\
\hline CS-23D & $28-30$ & $8.8 \mathrm{mg} / \mathrm{Kg}$ & 0.70 \\
\hline CS-23D & $33-35$ & $5.6 \mathrm{mg} / \mathrm{Kg}$ & 0.72 \\
\hline$C S-23 D$ & $38-40$ & $5.0 \mathrm{mg} / \mathrm{Kg}$ & 0.72 \\
\hline CS-23D & $43-45$ & $11.0 \mathrm{mg} / \mathrm{Kg}$ & 0.72 \\
\hline CS-23D & $48-50$ & $7.4 \mathrm{mg} / \mathrm{Kg}$ & 0.76 \\
\hline CS-24D & $3-5$ & $6.6 \mathrm{mg} / \mathrm{Kg}$ & 1.40 \\
\hline CS-24D & $8-10$ & $7.7 \mathrm{mg} / \mathrm{Kg}$ & 1.30 \\
\hline CS-24D & $13-15$ & $11.6 \mathrm{mg} / \mathrm{Kg}$ & 1.40 \\
\hline CS-24D & $18-20$ & $4.7 \mathrm{mg} / \mathrm{Kg}$ & 1.40 \\
\hline CS-24D & $23-25$ & $7.2 \mathrm{mg} / \mathrm{Kg}$ & 1.40 \\
\hline CS-24D & $28-30$ & $4.9 \mathrm{mg} / \mathrm{Kg}$ & 0.70 \\
\hline CS-24D & $33-35$ & $3.8 \mathrm{mg} / \mathrm{Kg}$ & 0.70 \\
\hline$C S-24 D$ & $38-40$ & $4.3 \mathrm{mg} / \mathrm{Kg}$ & 0.70 \\
\hline$C S-24 D$ & $43-45$ & $3.2 \mathrm{mg} / \mathrm{Kg}$ & 0.71 \\
\hline CS-24D & $48-50$ & $4.2 \mathrm{mg} / \mathrm{Kg}$ & 0.72 \\
\hline CS-2SD & $3-5$ & $6.3 \mathrm{mg} / \mathrm{Kg}$ & 0.67 \\
\hline CS-25D & $8-10$ & $17.0 \mathrm{mg} / \mathrm{Kg}$ & 1.50 \\
\hline CS-25D & $13-15$ & $5.3 \mathrm{mg} / \mathrm{Kg}$ & 0.73 \\
\hline CS-25D & $18-20$ & $5.1 \mathrm{mg} / \mathrm{Kg}$ & 0.68 \\
\hline CS-25D & $23-25$ & $9.0 \mathrm{mg} / \mathrm{Kg}$ & 0.67 \\
\hline CS-2SD & $28-30$ & $9.8 \mathrm{mg} / \mathrm{Kg}$ & 0.95 \\
\hline CS-25D & $33-35$ & $13.5 \mathrm{mg} / \mathrm{Kg}$ & 1.40 \\
\hline CS-25D & $38-40$ & $4.5 \mathrm{mg} / \mathrm{Kg}$ & 0.68 \\
\hline CS-25D & $43-45$ & $10.1 \mathrm{mg} / \mathrm{Kg}$ & 0.72 \\
\hline CS-25D & $48-50$ & $5.0 \mathrm{mg} / \mathrm{Kg}$ & 0.72 \\
\hline CS-26D & $3-5$ & $12.6 \mathrm{mg} / \mathrm{Kg}$ & 1.40 \\
\hline CS-26D & $8-10$ & $6.6 \mathrm{mg} / \mathrm{Kg}$ & 0.74 \\
\hline CS-26D & $13-15$ & $5.9 \mathrm{mg} / \mathrm{Kg}$ & 0.72 \\
\hline CS-26D & $18-20$ & $6.8 \mathrm{mg} / \mathrm{Kg}$ & 0.71 \\
\hline$C S-26 D$ & $23-25$ & $5.4 \mathrm{mg} / \mathrm{Kg}$ & 0.72 \\
\hline$C S-26 D$ & $28-30$ & $5.0 \mathrm{mg} / \mathrm{Kg}$ & 0.71 \\
\hline$C S-26 D$ & $33-35$ & $11.1 \mathrm{mg} / \mathrm{Kg}$ & 0.70 \\
\hline$C S-26 D$ & $38-40$ & $3.9 \mathrm{mg} / \mathrm{Kg}$ & 0.68 \\
\hline CS-26D & $43-45$ & $6.2 \mathrm{mg} / \mathrm{Kg}$ & 0.69 \\
\hline
\end{tabular}


Characterization and Reclamatior for the Central Shops Diesel Storage Facility at the Savannah River Site

Table 3. Concentration of Lead at Depth in the Sediments of Central Shops Diesel Storage Facility (Contd)

\begin{tabular}{|c|c|c|c|}
\hline Well ID & Depth (fit) & Concentration & Detection Limit \\
\hline CS-26D & $48-50$ & $5.0 \mathrm{mg} / \mathrm{Kg}$ & 0.73 \\
\hline CS-27D & $3-5$ & $10.9 \mathrm{mg} / \mathrm{Kg}_{\mathrm{g}}$ & 0.70 \\
\hline CS-27D & $8-10$ & $6.0 \mathrm{mg} / \mathrm{Kg}$ & 0.72 \\
\hline CS-27D & $13-15$ & $5.6 \mathrm{mg} / \mathrm{Kg}$ & 0.70 \\
\hline CS-27D & $18-20$ & $1.7 \mathrm{mg} / \mathrm{Kg}$ & 0.69 \\
\hline CS-27D & $23-25$ & $5.3 \mathrm{mg} / \mathrm{Kg}$ & 0.74 \\
\hline CS-27D & $28-30$ & $5.0 \mathrm{mg} / \mathrm{Kg}$ & 0.69 \\
\hline CS-27D & $33-35$ & $3.6 \mathrm{mg} / \mathrm{Kg}$ & 0.74 \\
\hline CS-27D & $38-40$ & $2.9 \mathrm{mg} / \mathrm{Kg}$ & 0.71 \\
\hline CS-27D & $43-45$ & $4.1 \mathrm{mg} / \mathrm{Kg}$ & 0.70 \\
\hline$C S-27 D$ & $48-50$ & $7.0 \mathrm{mg} / \mathrm{Kg}$ & 0.77 \\
\hline CS-28D & $3-5$ & $6.0 \mathrm{mg} / \mathrm{Kg}$ & 0.66 \\
\hline CS-28D & $8-10$ & $7.8 \mathrm{mg} / \mathrm{Kg}$ & 0.70 \\
\hline CS-28D & $13-15$ & $6.9 \mathrm{mg} / \mathrm{Kg}$ & 0.69 \\
\hline CS-28D & $18-20$ & $5.2 \mathrm{mg} / \mathrm{Kg}$ & 0.70 \\
\hline CS-28D & $23-25$ & $7.6 \mathrm{mg} / \mathrm{Kg}$ & 0.71 \\
\hline CS-28D & $28-30$ & $8.5 \mathrm{mg} / \mathrm{Kg}$ & 0.70 \\
\hline CS-28D & $33-35$ & $5.6 \mathrm{mg} / \mathrm{Kg}$ & 0.70 \\
\hline CS-28D & $38-40$ & $5.4 \mathrm{mg} / \mathrm{Kg}$ & 0.74 \\
\hline$C S-28 D$ & $43-45$ & $10.7 \mathrm{mg} / \mathrm{Kg}$ & 0.75 \\
\hline CS-28D & $48-50$ & $5.1 \mathrm{mg} / \mathrm{Kg}$ & 0.73 \\
\hline CS-28D & $53-55$ & $5.6 \mathrm{mg} / \mathrm{Kg}$ & 0.75 \\
\hline CS-29D & $3-5$ & $8.7 \mathrm{mg} / \mathrm{Kg}$ & 0.71 \\
\hline CS-29D & $8-10$ & $8.4 \mathrm{mg} / \mathrm{Kg}$ & 0.70 \\
\hline CS-29D & 13,15 & $6.9 \mathrm{mg} / \mathrm{Kg}$ & 0.72 \\
\hline CS-29D & $18-20$ & $4.2 \mathrm{mg} / \mathrm{Kg}$ & 0.71 \\
\hline CS-29D & $23-25$ & $5.2 \mathrm{mg} / \mathrm{Kg}$ & 0.72 \\
\hline CS-29D & $28-30$ & $4.5 \mathrm{mg} / \mathrm{Kg}$ & 0.70 \\
\hline CS-29D & $33-35$ & $7.2 \mathrm{mg} / \mathrm{Kg}$ & 0.73 \\
\hline CS-29D & $38-40$ & $5.8 \mathrm{mg} / \mathrm{Kg}$ & 0.75 \\
\hline CS-29D & $43-45$ & $6.1 \mathrm{mg} / \mathrm{Kg}$ & 0.75 \\
\hline CS-29D & $48-50$ & $8.1 \mathrm{mg} / \mathrm{Kg}$ & 0.76 \\
\hline
\end{tabular}


Table 4. Maximum Concentration of Lead in the Groundwater and Sediments of Central Shops Storage Facility. Well

\begin{tabular}{lcccc} 
Well No. & $\begin{array}{c}\text { Screen Depth } \\
(\mathrm{ft})\end{array}$ & $\begin{array}{c}\text { Maximum Lead } \\
\text { Concentration } \\
\text { Water(ug/L) }\end{array}$ & $\begin{array}{c}\text { Maximum Lead } \\
\text { Concentration } \\
\text { in Sediments } \\
\text { (ug/Kg) }\end{array}$ & $\begin{array}{c}\text { Detection } \\
\text { Limits (ug/L) }\end{array}$ \\
\hline CS-15D & $83-84$ & 780.0 & 126 & 300.0 \\
CS-16D & $73-74$ & 15.4 & 89.1 & 3.0 \\
CS-17D & ND & ND & 222.7 & ND \\
CS-18D & $58-59$ & 4.4 & 59.2 & 4.4 \\
CS-19D & $58-59$ & 13.6 & 79.6 & 3.0 \\
CS-20D & $54-55$ & 30.0 & 58.2 & 30.0 \\
CS-21D & $64-65$ & 11.7 & 103 & 3.0 \\
CS-22D & $50-51$ & 600.0 & 94.3 & 300.0 \\
CS-23D & ND & 86.0 & 75.6 & 30.0 \\
CS-24D & $54-55$ & 4.7 & 58.2 & 3.0 \\
CS-25D & $54-55$ & 3.0 & 85.6 & 3.0 \\
CS-26D & $52-53$ & 120.0 & 68.5 & 30.0 \\
CS-27D & $53-54$ & 40.0 & 52.1 & 30.0 \\
CS-28D & $58-59$ & 84.0 & 74.4 & 12.0 \\
CS-29D & $53-54$ & 26.1 & 65.1 & 3.0 \\
Mean & & 137.91 & 87.44 & \\
Standard deviation & & 242.54 & 42.31 & \\
ND & & No Data & &
\end{tabular}


Characterization and Reclamation for the Central Shops Diesel Storage Facility at the Savannah River Site

Table 5. Densities of Total Heterotrophic and Diesel Utilizing Bacteria in Sediments Containing Total Petroleum Hydrocarbons from Central Shops Diesel Fuel Facility with Respect to TPH Concentrations

\begin{tabular}{|c|c|c|}
\hline $\begin{array}{l}\text { TPH Concentration in } \\
\text { Sediments } \\
(\text { ppm/gdw) }\end{array}$ & $\begin{array}{l}\text { Total Heterotrophs } \\
\text { (cfu/gdw) }\end{array}$ & $\begin{array}{l}\text { Diesel Utilizers } \\
\text { (cfu/gdw) }\end{array}$ \\
\hline 665 & 2,800 & 200 \\
\hline 75 & 1000 & 200 \\
\hline 887 & 1000 & 200 \\
\hline 74 & 100 & 200 \\
\hline 156 & 100 & 200 \\
\hline 91 & 100 & 200 \\
\hline 132 & 100 & 200 \\
\hline 87 & 100 & 200 \\
\hline 70 & 400 & 200 \\
\hline 76 & 100 & 200 \\
\hline 603 & 520,000 & 22,400 \\
\hline 5,040 & 100 & 200 \\
\hline 273 & 100 & 200 \\
\hline 57 & 100 & 200 \\
\hline 383 & 200 & 200 \\
\hline 229 & 100 & 200 \\
\hline 265 & 100 & 200 \\
\hline 269 & 1000 & 400 \\
\hline 384 & 300 & 200 \\
\hline 301 & 100 & 200 \\
\hline 79 & 100 & 200 \\
\hline 2,413 & 300 & 200 \\
\hline 468 & 100 & 200 \\
\hline 4,377 & 300 & 200 \\
\hline 475 & 100 & 200 \\
\hline 965 & 600 & 200 \\
\hline 492 & 200 & 1,000 \\
\hline 136 & 100 & 200 \\
\hline 392 & 100 & 200 \\
\hline 101 & 100 & 200 \\
\hline 69 & 100 & 200 \\
\hline 84 & 100 & 200 \\
\hline 94 & 100 & 200 \\
\hline
\end{tabular}


WSRC-TR-94-0344

Table 6. Amendments and Concentrations Used in Biodegradability Investigations

\begin{tabular}{lc} 
Amendments & $\begin{array}{c}\text { Concentrations } \\
\text { (mg/L) }\end{array}$ \\
\hline phosphate & 687 \\
potassium & 160 \\
ammonia & 336 \\
carbonate & 57 \\
calcium & 3.6 \\
magnesium & 19.5 \\
manganese & 4 \\
iron & 1 \\
sulfate & 87 \\
chloride & 670 \\
sodium & 172
\end{tabular}


Table 7. Cell Yields $(\mathrm{mg} / \mathrm{L})$ for Combinations of Inorganic Nutrients

\begin{tabular}{|c|c|c|c|c|c|c|c|c|c|}
\hline Test \# & $\mathrm{PO}_{4}$ & $\mathrm{NH}_{4}$ & $\mathrm{CO}_{3}$ & $\mathrm{Ca}$ & $\mathbf{M g}$ & $\mathbf{M n}$ & $\mathbf{F e}$ & $\begin{array}{l}\text { Diesel } \\
\text { Fuel }\end{array}$ & $\begin{array}{c}\text { Cell } \\
\text { Yield (mg/l) }\end{array}$ \\
\hline 1 & & & & & & & & & 24 \\
\hline 2 & & & & & & & & + & 26 \\
\hline 3 & + & & & & & & & + & 38 \\
\hline 4 & & + & & & & & & + & 42 \\
\hline 5 & + & + & & & & & & + & 170 \\
\hline 6 & + & + & & & & & & + & 158 \\
\hline 7 & + & + & + & & & & & + & 178 \\
\hline 8 & + & + & & + & & & & + & 154 \\
\hline 9 & + & + & & & + & & & + & 268 \\
\hline 10 & + & + & & & & + & & + & 218 \\
\hline 11 & + & + & & & & & + & + & 94 \\
\hline 12 & + & + & + & + & & & & + & 142 \\
\hline 13 & + & + & + & & + & & & + & 132 \\
\hline 14 & + & + & + & & & + & & + & 78 \\
\hline 15 & + & + & + & & & & + & + & 100 \\
\hline 16 & + & + & & + & + & & & + & 132 \\
\hline 17 & + & + & & + & & + & & + & 98 \\
\hline 18 & + & + & & + & & & + & + & 60 \\
\hline 19 & + & + & & & + & + & & + & 158 \\
\hline 20 & + & + & & & + & & + & + & 224 \\
\hline 21 & + & + & & & & + & + & + & 162 \\
\hline 22 & + & + & + & + & + & & & + & 52 \\
\hline 23 & + & + & + & + & + & + & & + & 116 \\
\hline 24 & + & + & + & + & + & + & + & + & 122 \\
\hline 25 & + & + & + & + & + & + & + & + & 152 \\
\hline 26 & + & + & + & + & + & + & + & + & 262 \\
\hline 27 & + & + & & + & + & + & + & + & 396 \\
\hline 28 & + & + & + & & + & + & + & + & 288 \\
\hline 29 & + & + & + & + & & + & + & + & 166 \\
\hline 30 & + & + & + & + & + & & + & + & 188 \\
\hline 31 & + & + & & & + & + & + & + & 254 \\
\hline 32 & + & + & & + & & + & + & + & 218 \\
\hline 33 & + & + & & + & + & & + & + & 234 \\
\hline 34 & + & + & & + & + & + & & + & 240 \\
\hline 35 & + & + & + & & & & + & + & 196 \\
\hline 36 & + & + & + & & + & & + & + & 206 \\
\hline 37 & + & + & + & & + & + & & + & 214 \\
\hline 38 & + & + & + & + & & & + & + & 134 \\
\hline
\end{tabular}


Table 8. Nutrient Stability Tests for Borings CSD 13 (5-7 feet) and CSD 6 (10-12 feet)

\begin{tabular}{cccc} 
Borehole & Time (hr) & $\begin{array}{c}\text { Phosphate } \\
\text { (mg/L) }\end{array}$ & $\begin{array}{c}\text { Hydrogen } \\
\text { Peroxide } \\
\text { (mg/L) }\end{array}$ \\
\hline CSD-13D & 0 & 81 & 150 \\
CSD-13D & 0.5 & 59 & 105 \\
CSD-13D & 1 & 28 & 130 \\
CSD-13D & 3 & 14 & 95 \\
CSD-13D & 5 & 9 & 85 \\
CSD-13D & 21 & 4 & $<1$ \\
*SD-13D & 21 & 140 & 150 \\
CSD-13D & 25 & 90 & 100 \\
CSD-13D & 43 & 44 & 25 \\
CSD-6D & 0 & 280 & 265 \\
CSD-6D & 4 & 195 & 230 \\
CSD-6D & 8 & 150 & 109
\end{tabular}

**Additional phosphate and hydrogen peroxide added. 
Table 9. Column Investigations of Groundwater Flow Rate through Columns Packed with CSD-13D and CSD-6D Soils, Respectively

\begin{tabular}{|c|c|c|}
\hline Borebole & Treatment & Flow Rate (mL/min) \\
\hline CSD-13D & 1 & 17 \\
\hline CSD-13D & 2 & 15 \\
\hline CSD-13D & 3 & 14 \\
\hline CSD-13D & 4 & 11 \\
\hline CSD-13D & 5 & 11 \\
\hline CSD-13D & 6 & 10 \\
\hline${ }^{*}$ CSD-13D & 7 & $\begin{array}{c}22 \\
\text { (soil fines in effluent) }\end{array}$ \\
\hline CSD-13D & 8 & 10 \\
\hline CSD-13D & 9 & 4 \\
\hline CSD-13D & 10 & 2 \\
\hline CSD-13D & 11 & 1 \\
\hline${ }^{* *} \mathrm{CSD}-13 \mathrm{D}$ & 12 & 1 \\
\hline CSD-13D & 13 & 1.4 \\
\hline CSD-13D & 14 & Plugged \\
\hline CSD-6D & 1 & 18 \\
\hline CSD-6D & 2 & 18 \\
\hline CSD-6D & 3 & 17 \\
\hline CSD-6D & 4 & 46 \\
\hline CSD-6D & 5 & 21 \\
\hline CSD-6D & 6 & 13 \\
\hline CSD-6D & 7 & 12 \\
\hline CSD-6D & 8 & $\begin{array}{c}10 \\
\text { (soil fines in effluent) }\end{array}$ \\
\hline CSD-6D & 9 & 10 \\
\hline${ }^{* * *}$ CSD $-6 D$ & 10 & 4 \\
\hline CSD-6D & 11 & 2 \\
\hline CSD-6D & 12 & 1 \\
\hline CSD-6D & 13 & 1 \\
\hline
\end{tabular}

-PO4+NH4+Ca+Mg+Mn+CO3+Fe

- $\mathrm{PO} 4+\mathrm{NH} 4+\mathrm{Ca}+\mathrm{Mg}+\mathrm{Mn}+\mathrm{CO}+\mathrm{Fe}+160 \mathrm{ppm} \mathrm{H202}$

-**PO4+NH4+Ca+Mg+Mn+CO3+Fe+210 ppm H202 


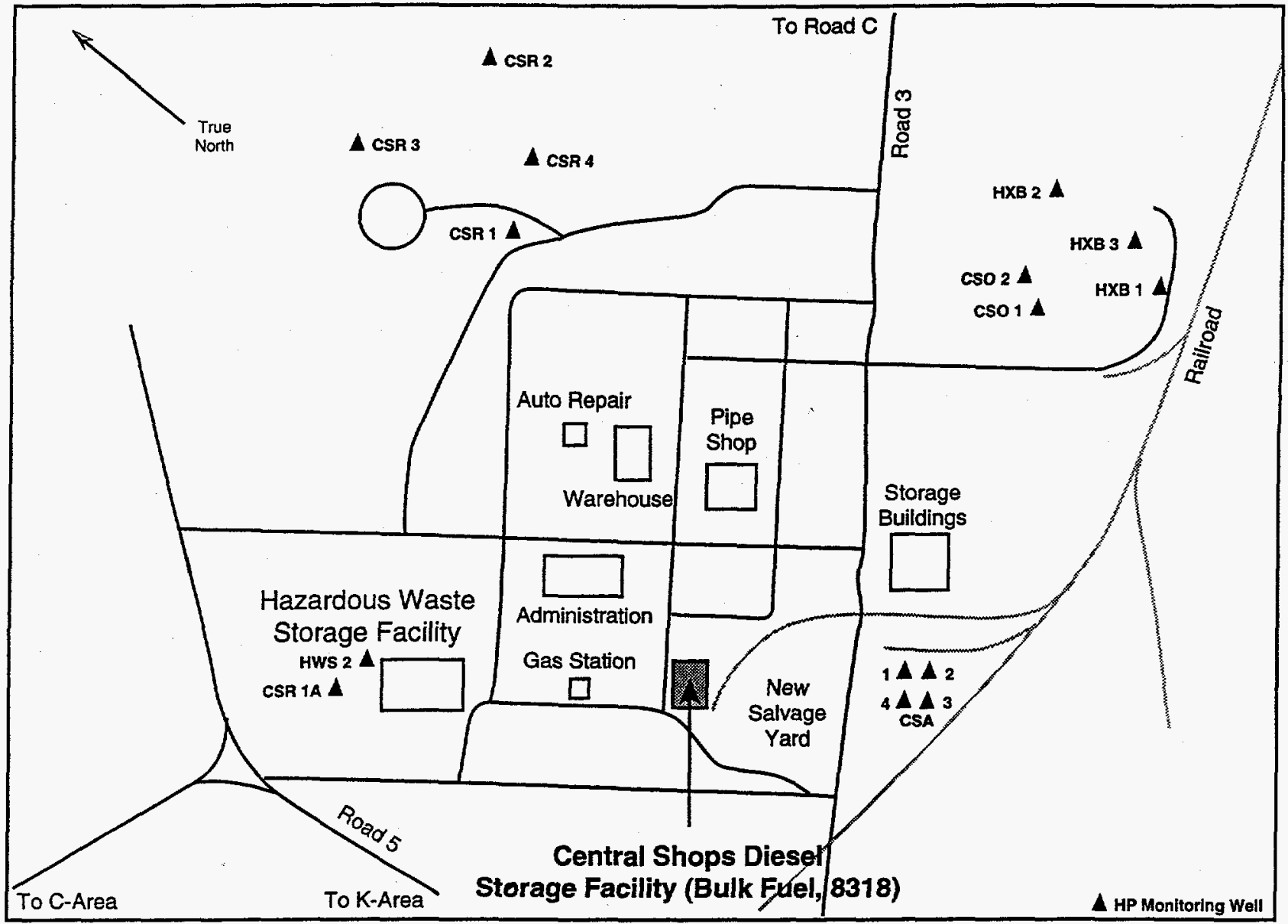

93X2164.05.AlL

Figure 1. Location of the Central Shops Diesel Storage Facility 


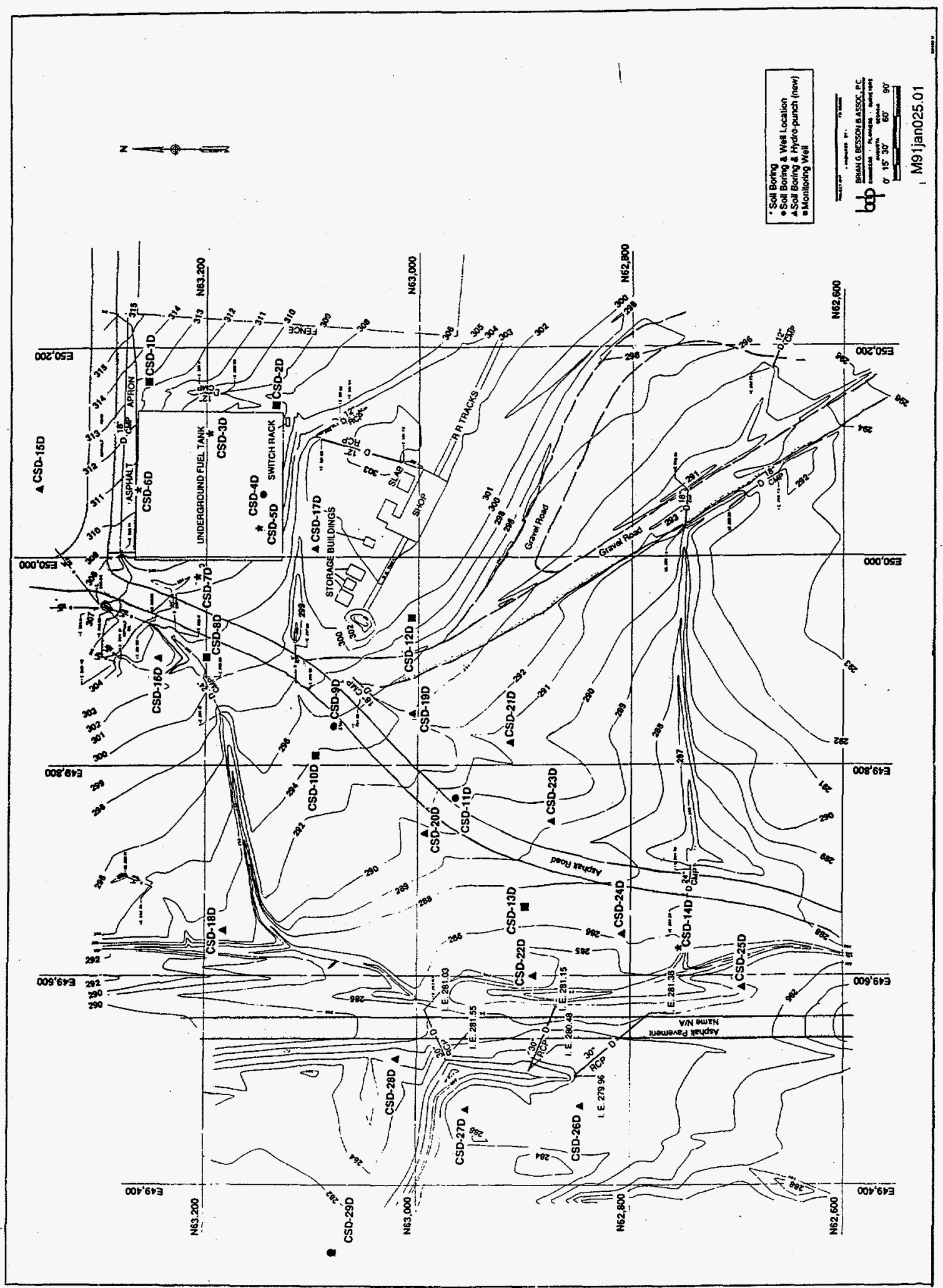

Figure 2. Characterization Area at Central Shops Diesel Storage Facility 


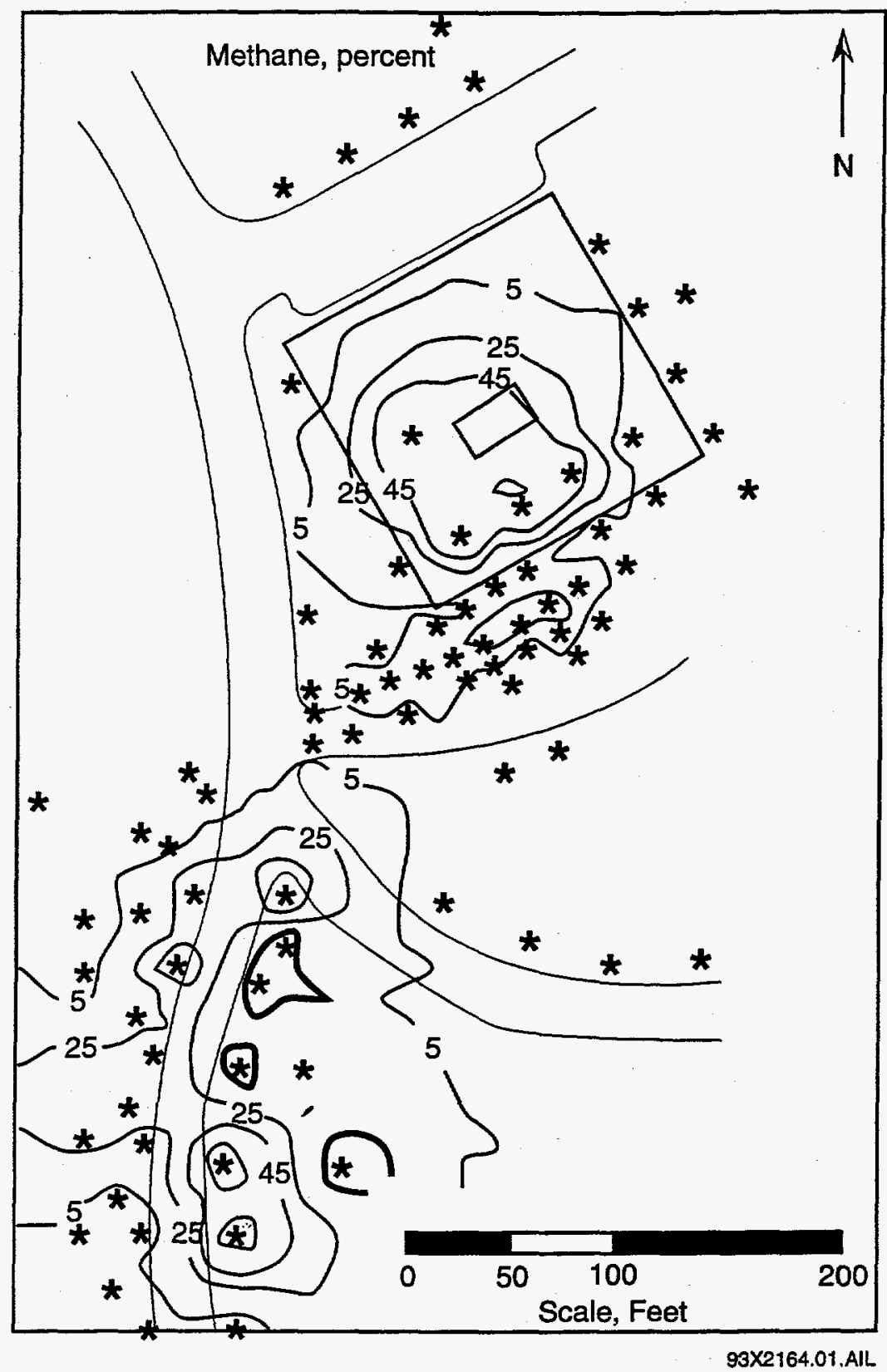

Figure 3. Concentration of Methane in Soil Gas (expressed in percentage) 
FORMATION NAMES

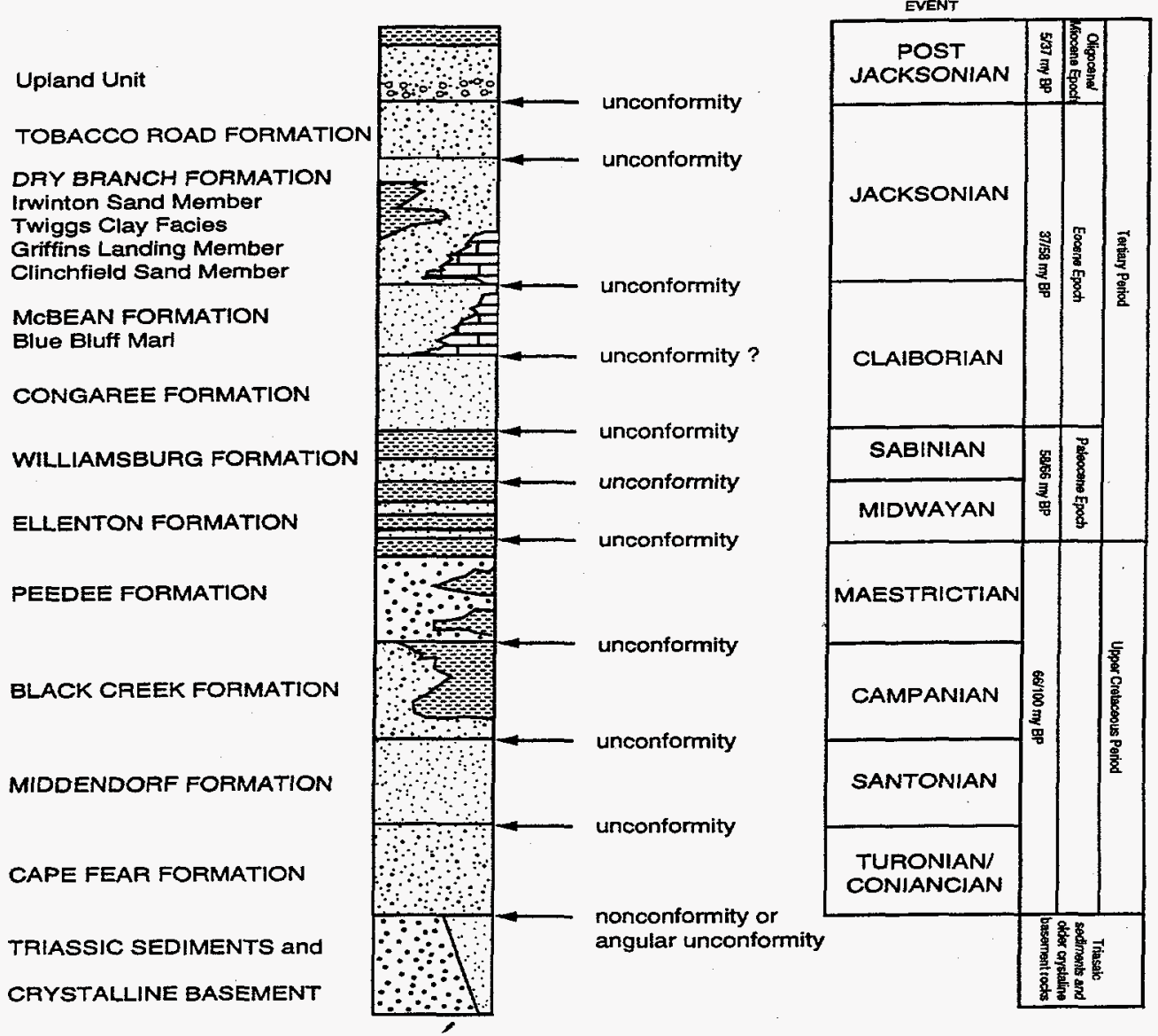

Figure 2. Generalized strategraphic section at the Savannah River Site.

$*$

Figure 4. Generalized Stratigraphic Section at the Savannah River Site 


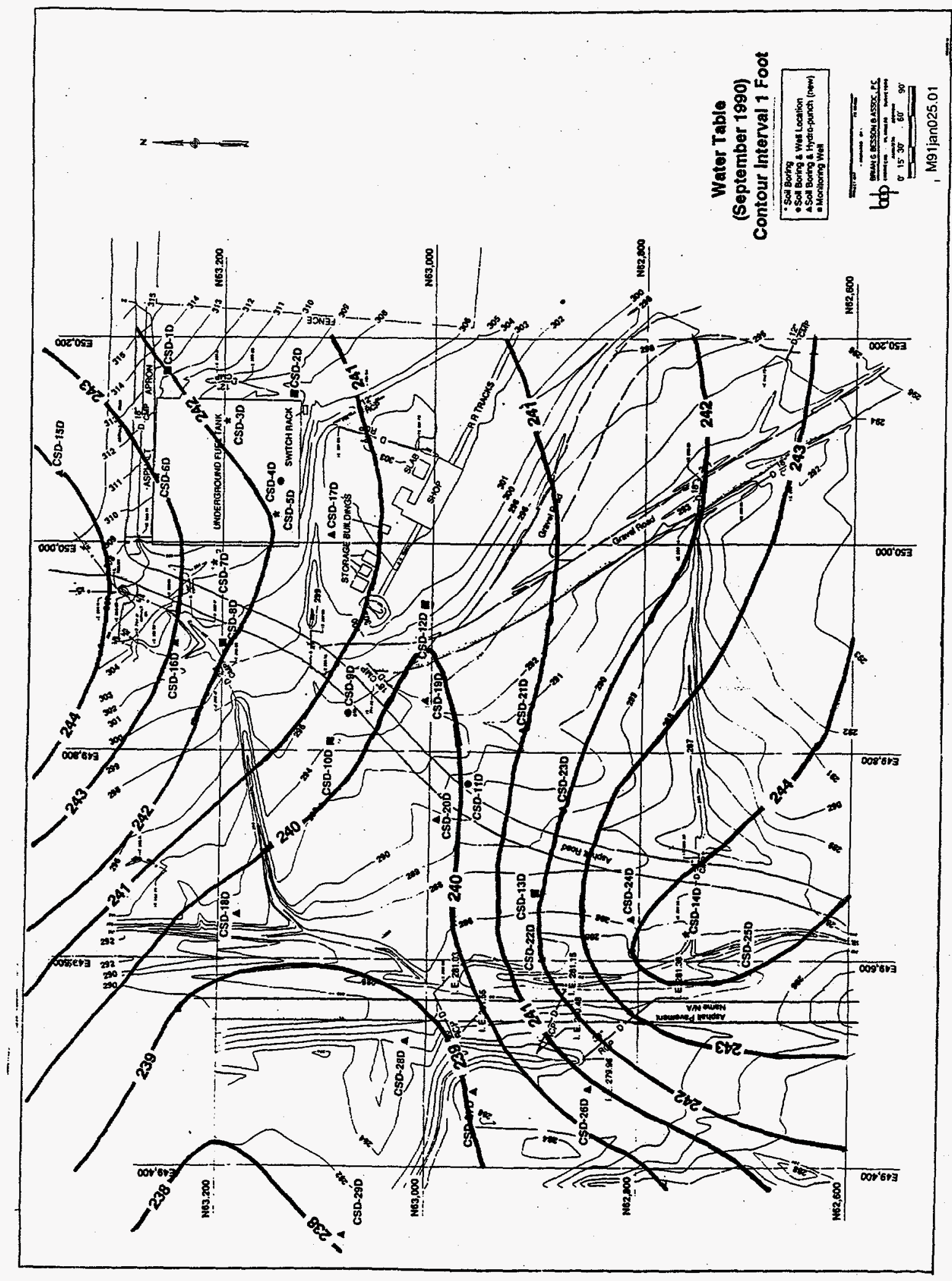

Figure 5. Contour Mapping of Water Table Elevations for Central Shops Diesel Storage Facility in September 1990 


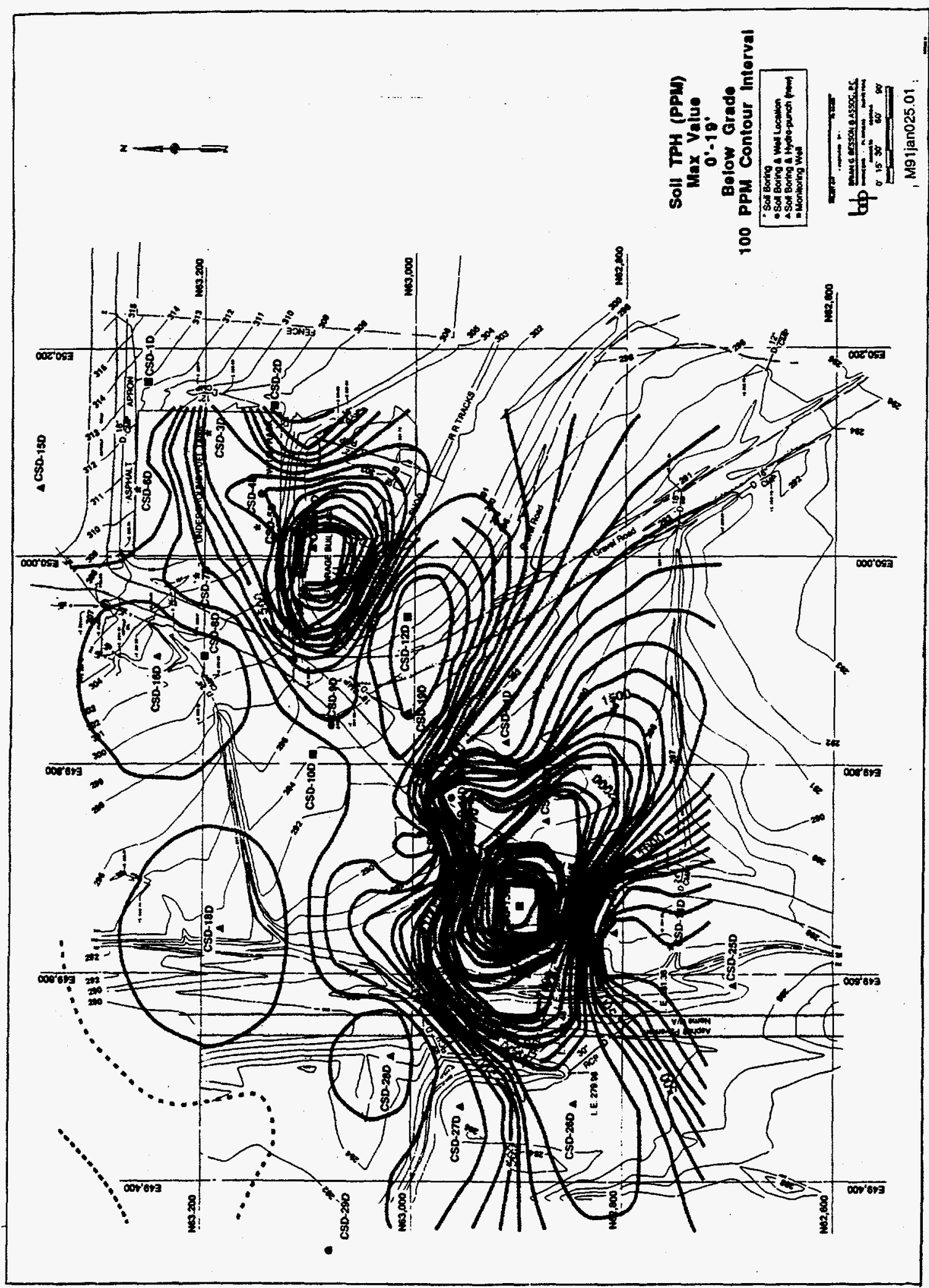

Figure 6. Two-Dimensional Contour Mapping of Maximum Total Petroleum Hydrocarbons at 100 ppm Intervals for Sediments 0 to 19 feet below the Soil Surface 


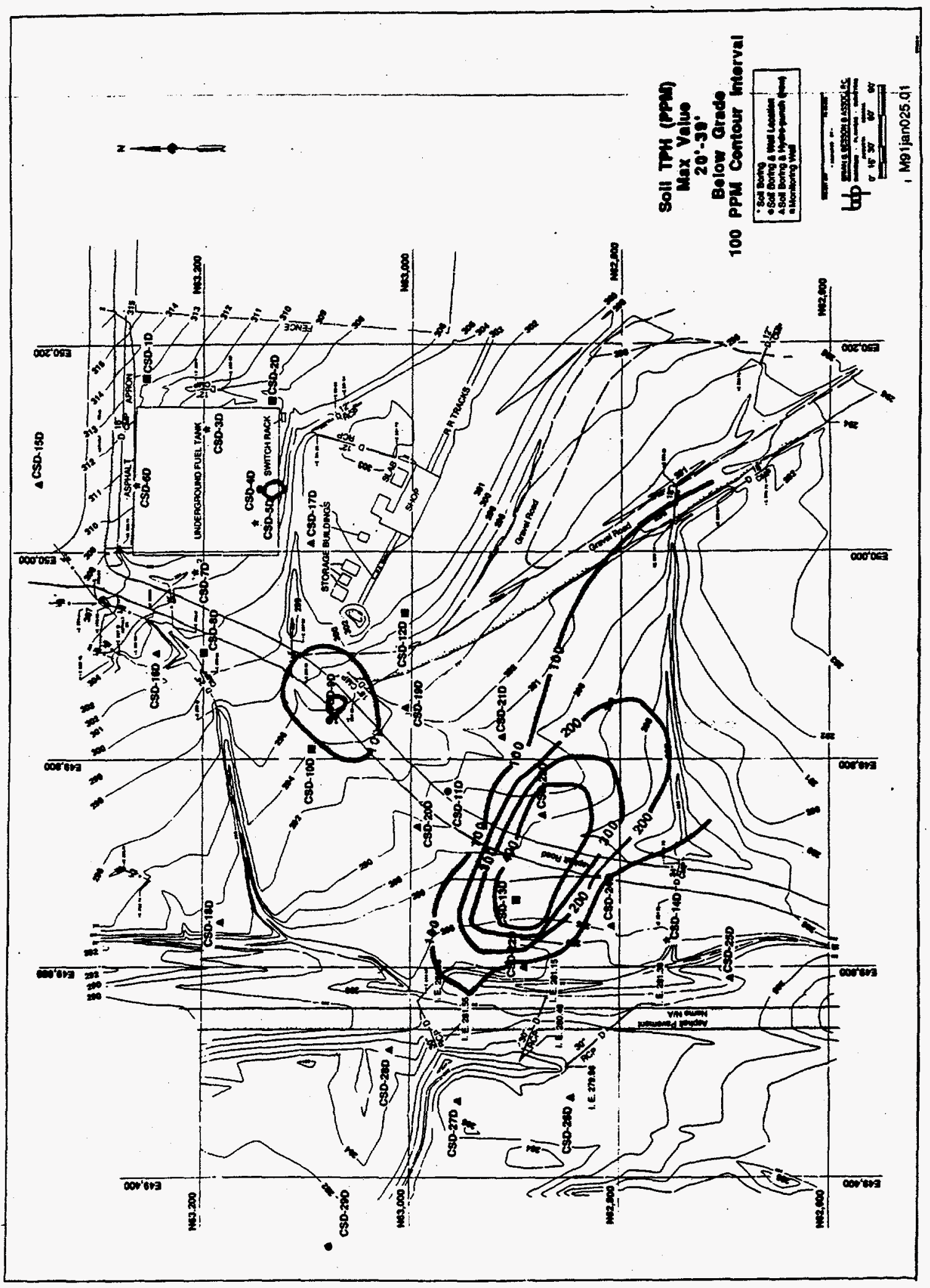

Figure 7. Two-Dimensional Contour Mapping of Maximum Total Petroleum Hydrocarbons at $100 \mathrm{ppm}$ Intervals for Sediments 20 to 39 feet below the Soil Surface 


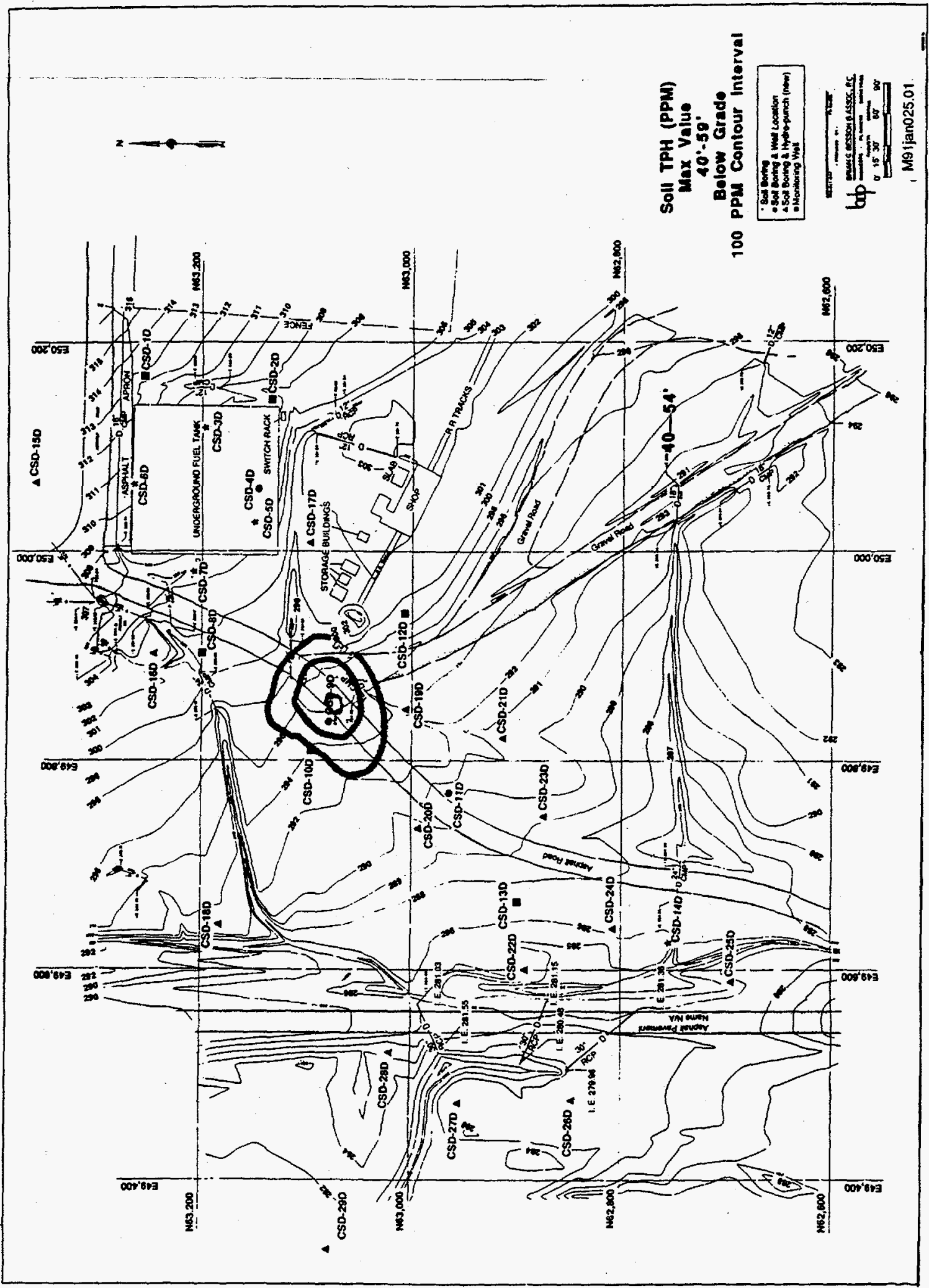

Figure 8. Two-Dimensional Contour Mapping of Maximum Total Petroleum at $100 \mathrm{ppm}$ Intervals for Sediments 40 to 59 Feet below the Soil Surface 


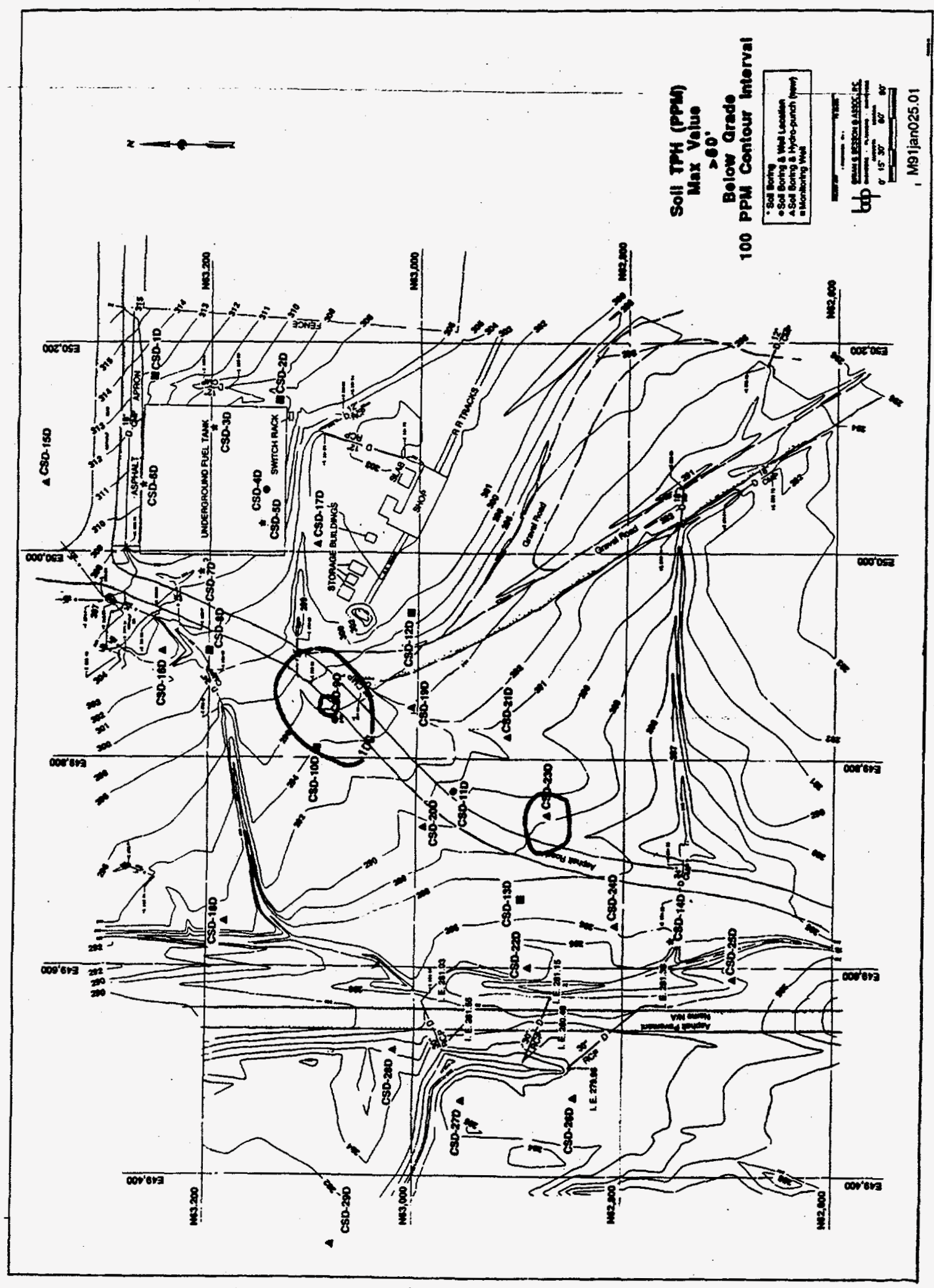

Figure 9. Two-Dimensional Contour Mapping of Maximum Total Petroleum Hydrocarbons at $100 \mathrm{ppm}$ Intervals for Sediments Greater than 60 Feet below the Soil Surface 

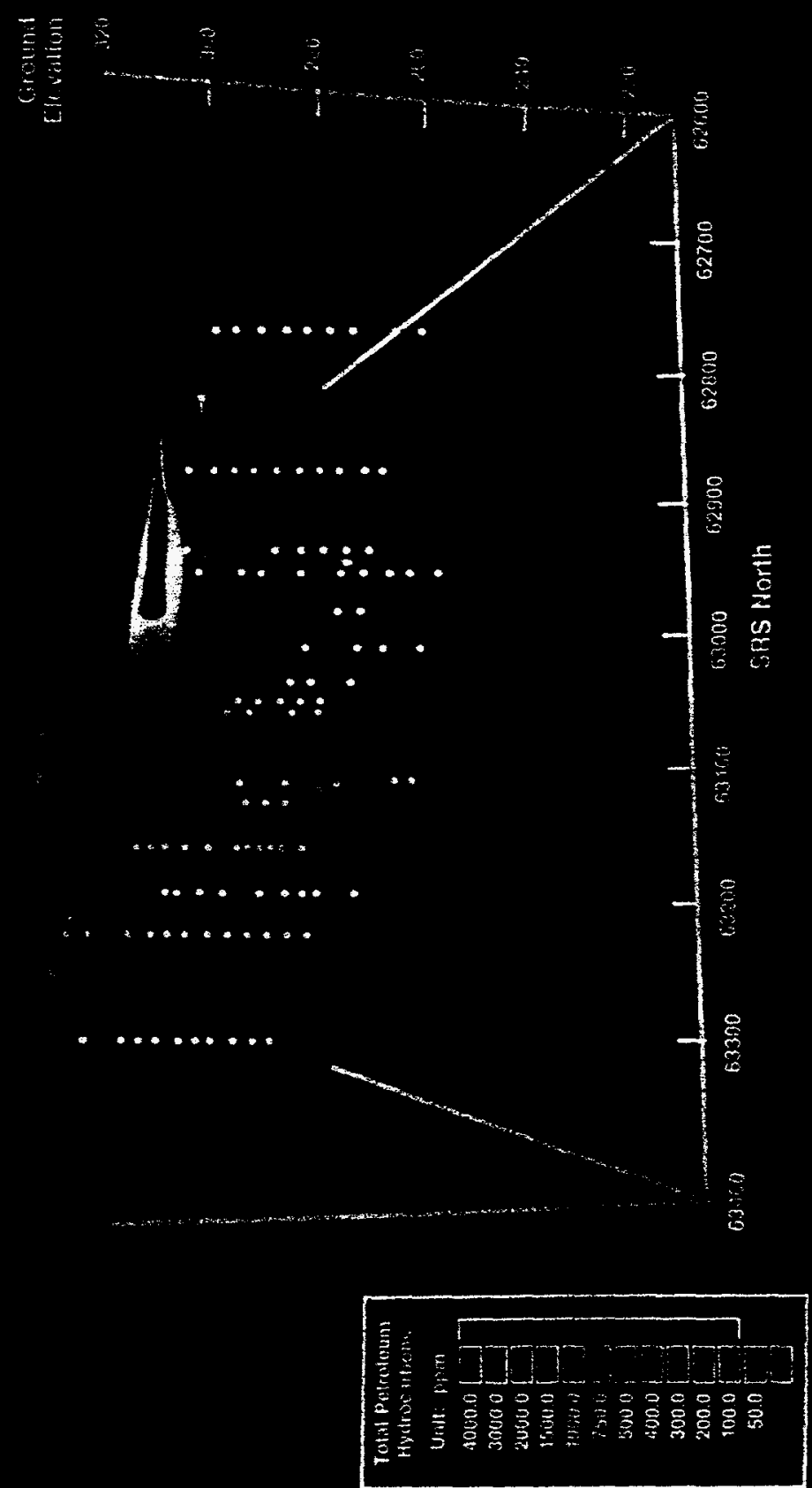

Figure 10. Three-Dimensional Contour Mapping of Maximum Total Petroleum Hydrocarbons at 100 ppm Intervals for Sediments at Depth below the Soil Surface 


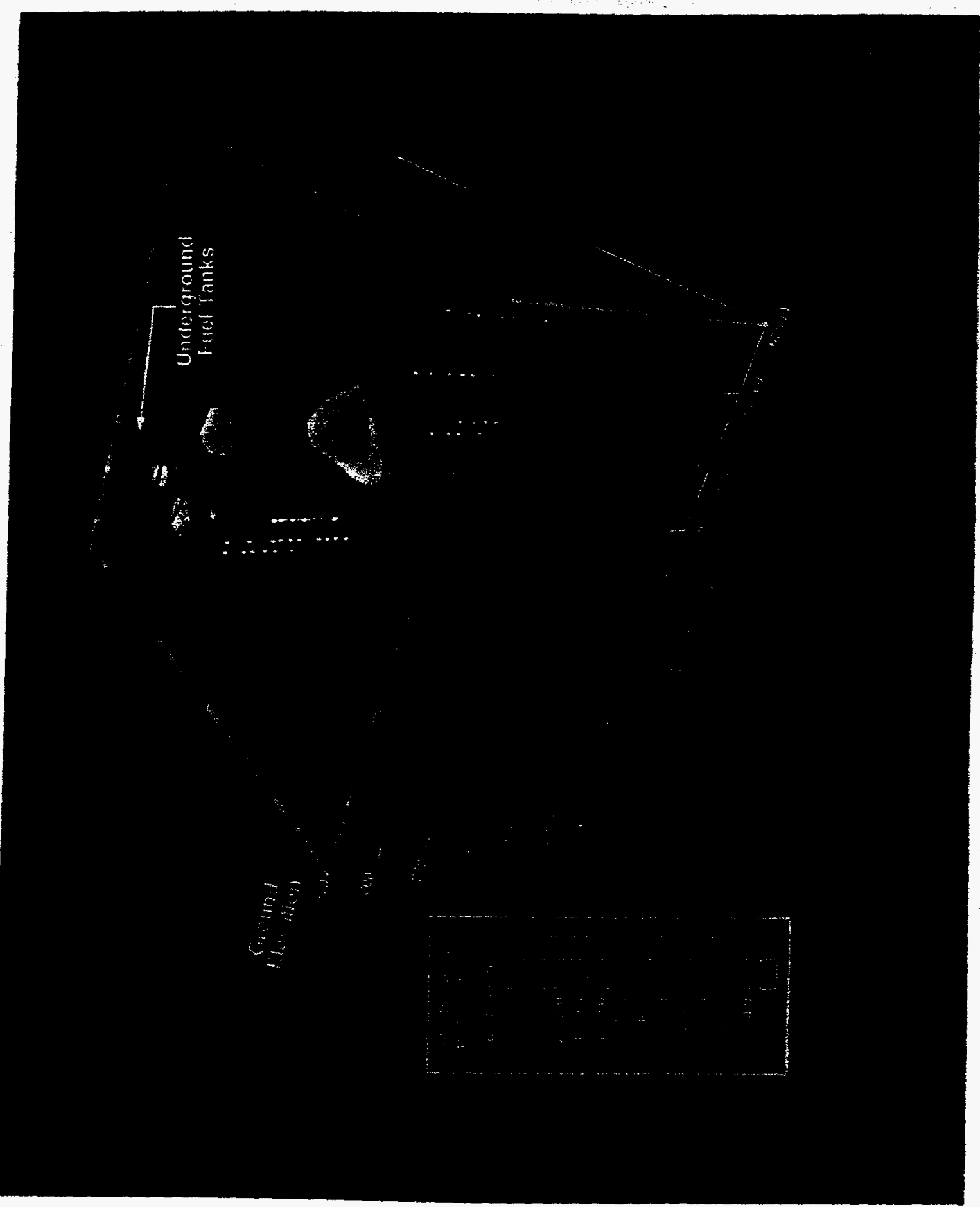

Figure 11. Three-Dimensional Contour Mapping of Maximum Total Petroleum Hydrocarbons at $100 \mathrm{ppm}$ Intervals for Sediments at Depth below the Soil Surface (b) 

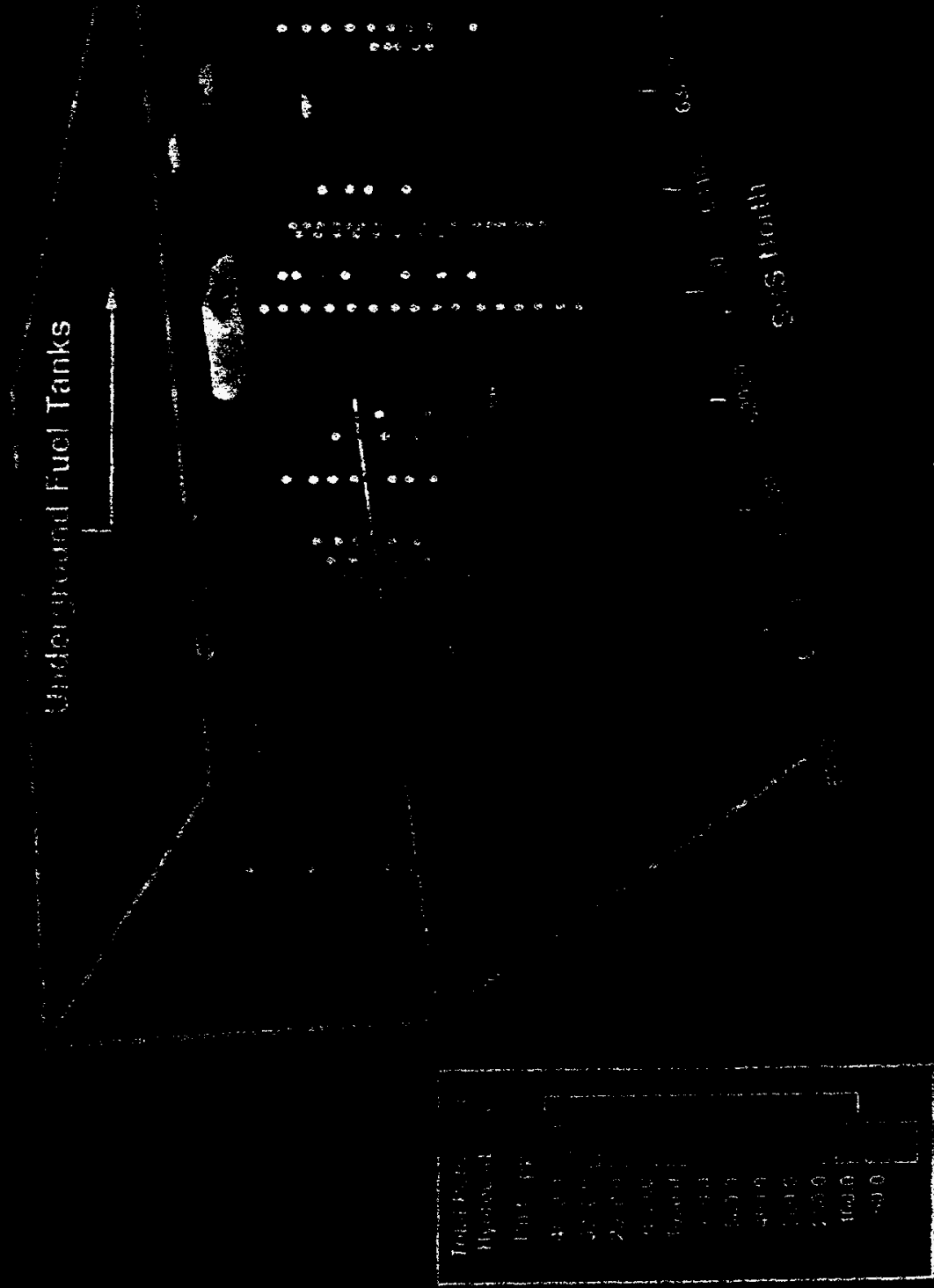

Figure 12. Three-Dimensional Contour Mapping of Maximum Total Petroleum Hydrocarbons at $100 \mathrm{ppm}$ Intervals for Sediments at Depth below the Soil Surface (c) 


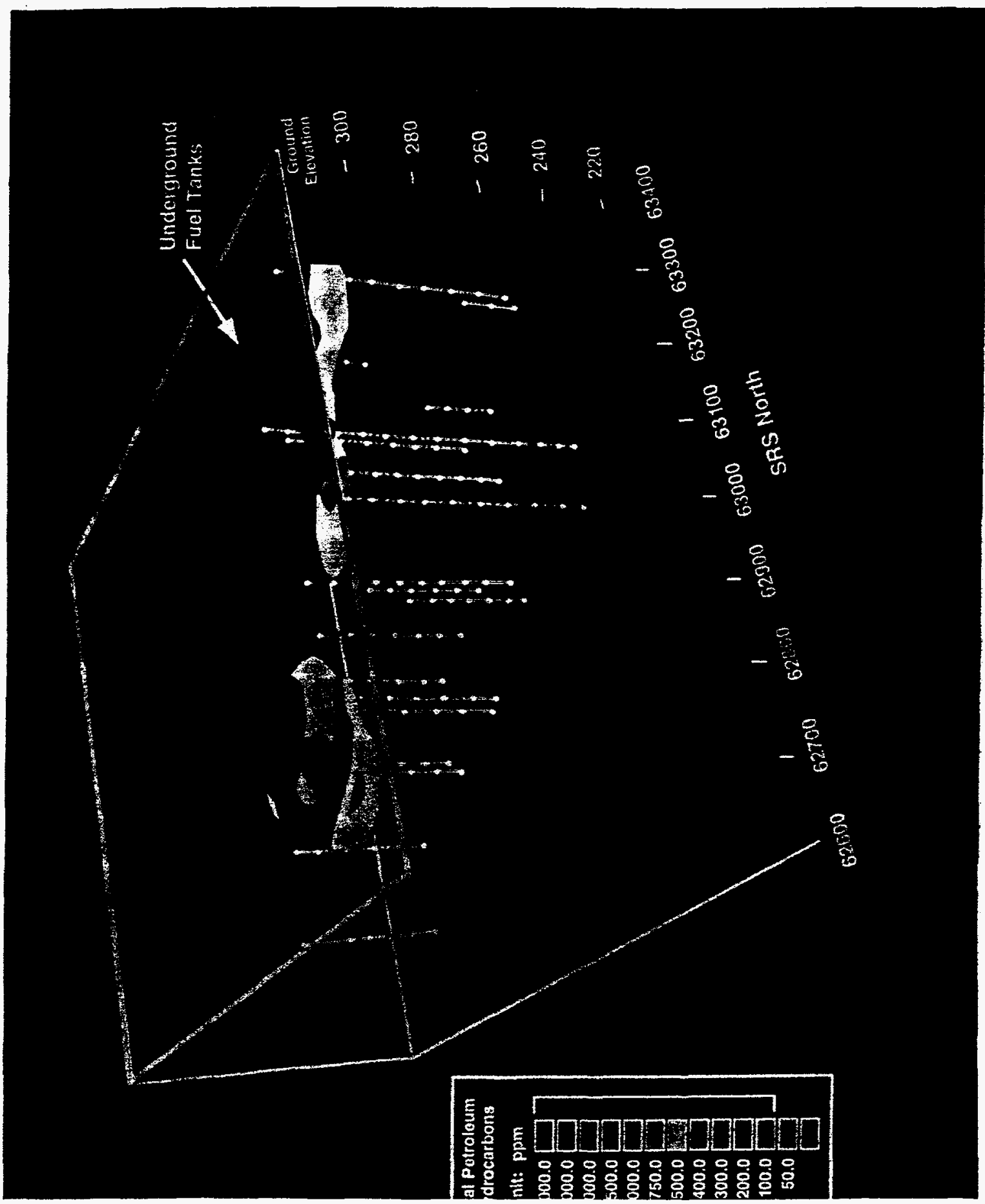

Figure 13. Three-Dimensional Contour Mapping of Maximum Total Petroleum Hydrocarbons at 100 ppm Intervals for Sediments at Depth below the Soil Surface (d) 


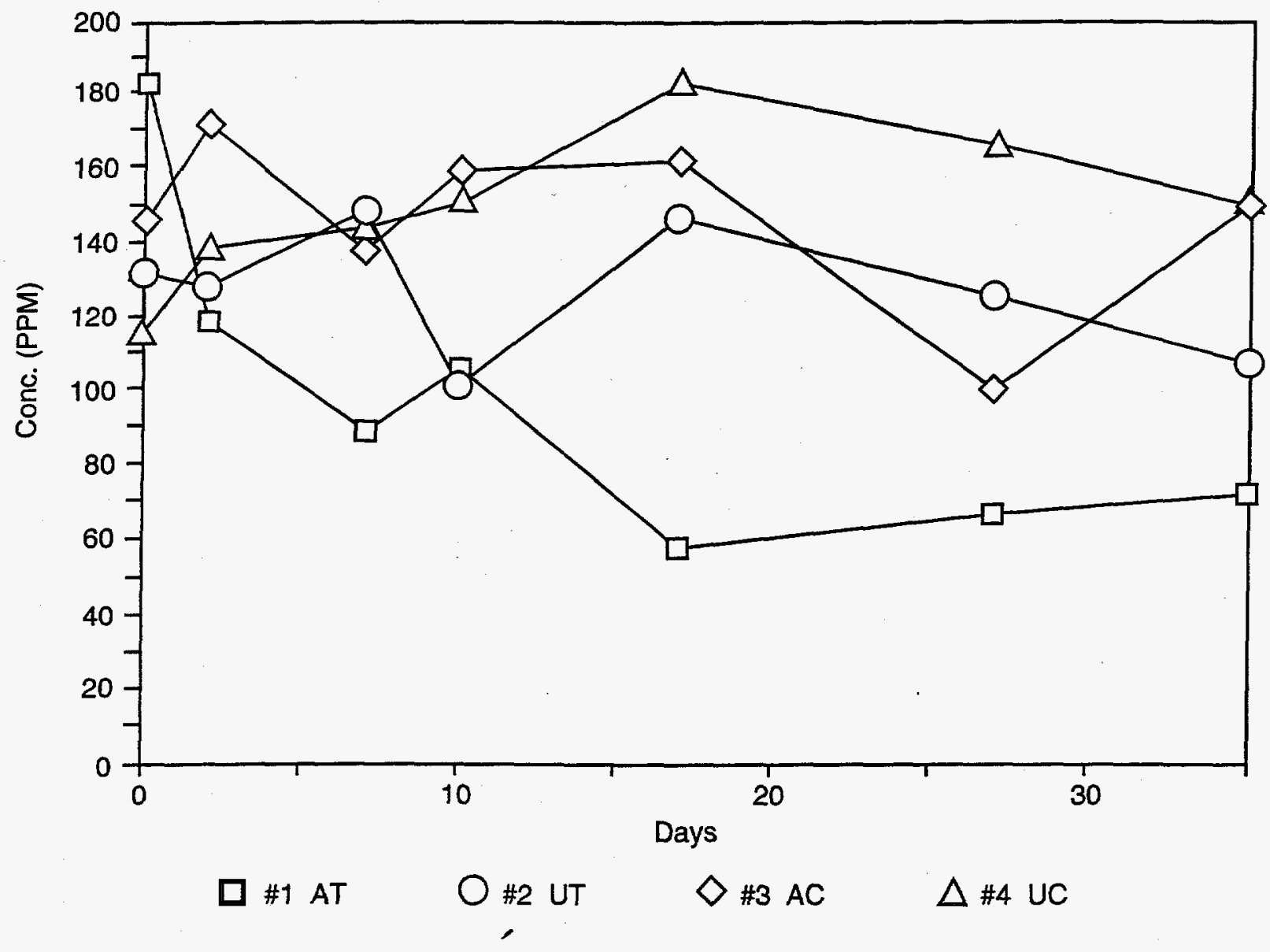

93X2164.02.AlL

Figure 14. Biological Degradation of Biological Volatile TPH in Laboratory Microcosms with a Variety of Amendments 


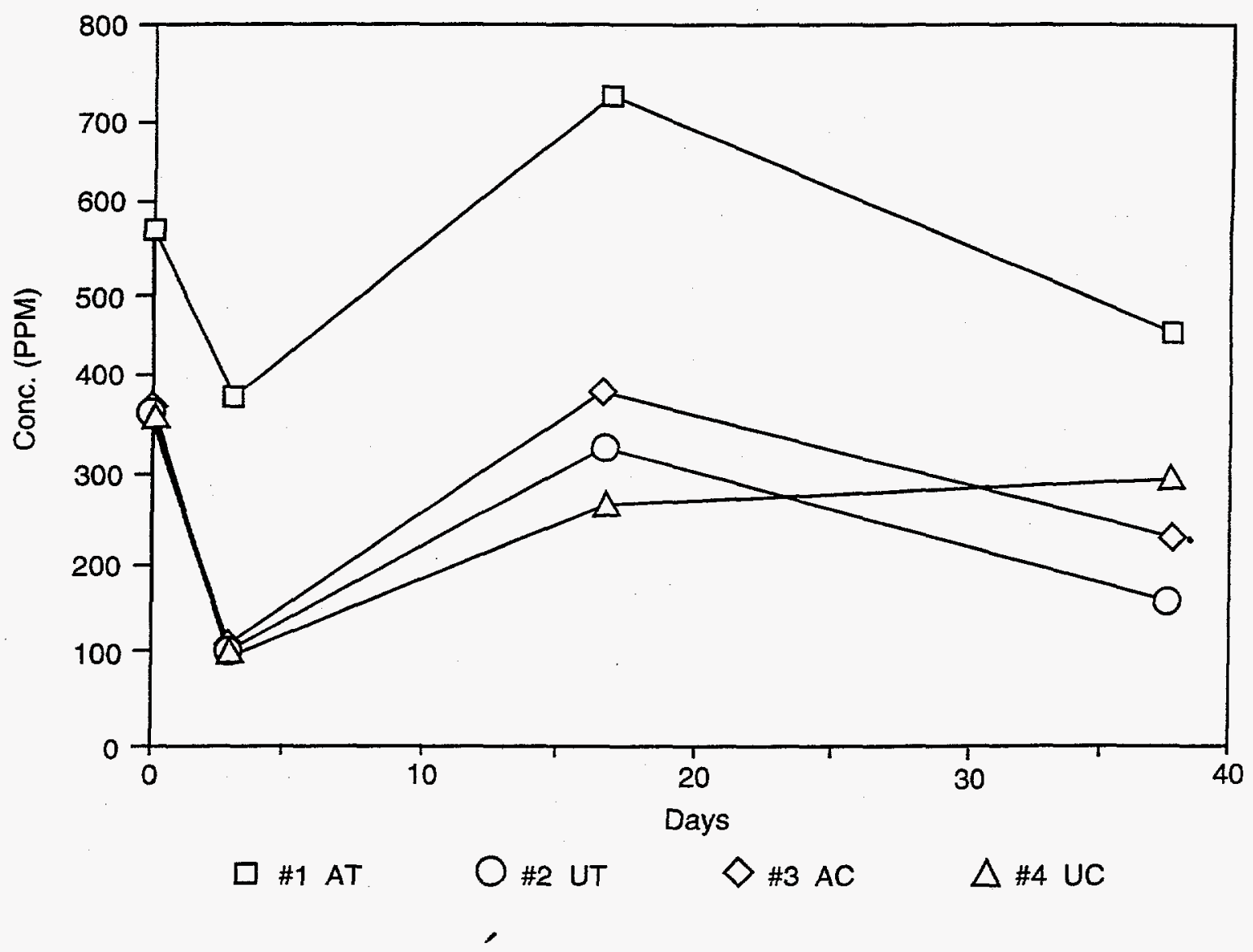

93X2164.03.All

Figure 15. Biological Degradation of TPH in Laboratory Microorganisms with a Variety of Amendments 


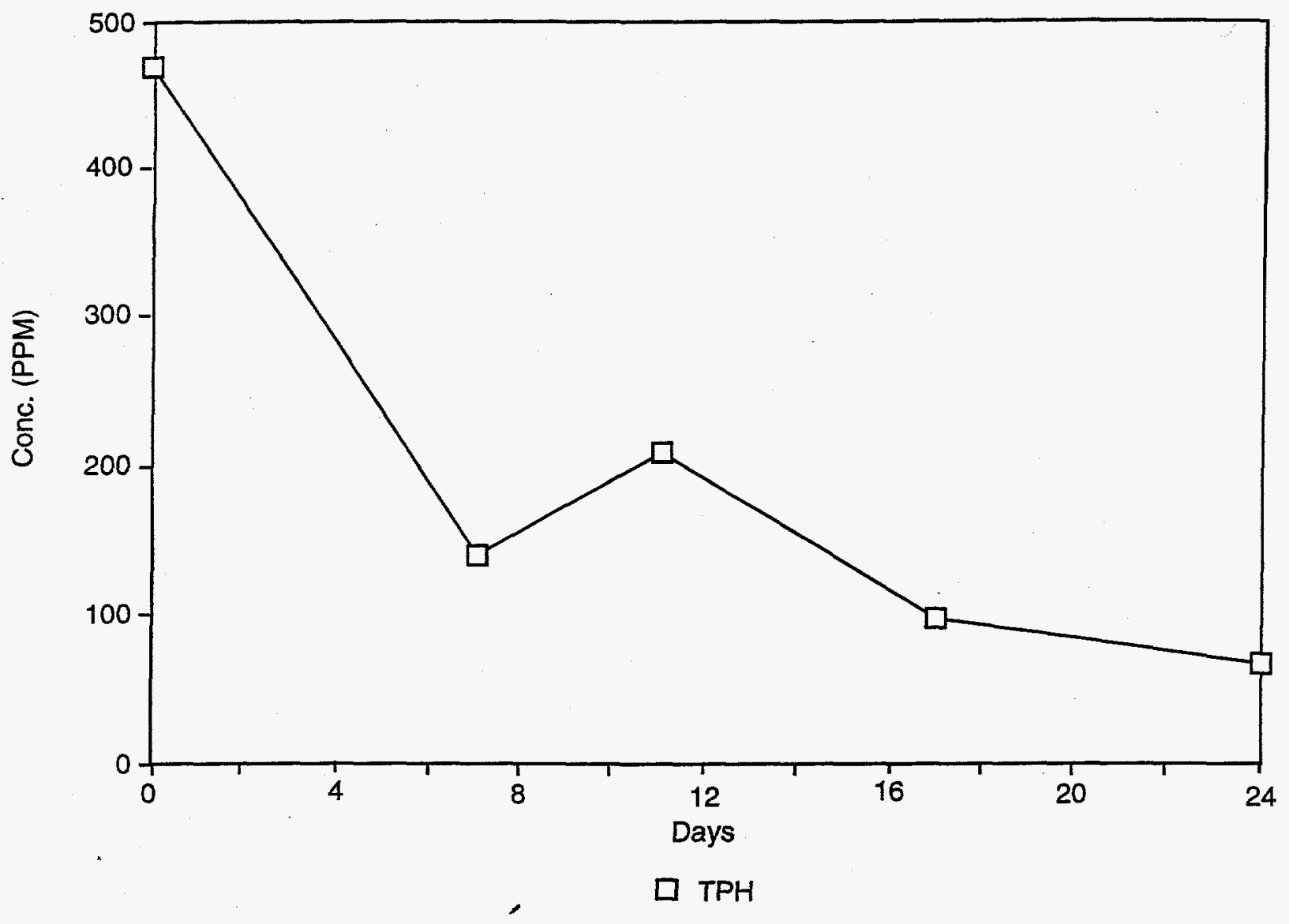

93X2164.04.AlL

Figure 16. Vacuum Extraction of CSD-13D Soils Containing TPH 


\section{Appendix I \\ Lancaster Laboratories, Inc. Analysis Reports of Water Samples}


Well Number: CSD-13D

LUI Sample Number: WW 1376373

Water Sample: \#856

Collected on: April 5, 1989

Table 1. Lancaster Laboratories, Inc. Analysis Report of Water Samples from CSD-13D

\begin{tabular}{lccc}
\multicolumn{1}{c}{ Acid Extractables } & $\begin{array}{c}\text { Result } \\
\text { as Recelved }\end{array}$ & $\begin{array}{c}\text { Limit of } \\
\text { Quantitation }\end{array}$ & Lab Code \\
\hline 2-Chlorophenol & $<20 . \mathrm{ug} / 1$ & 20. & $064600000 \mathrm{~N}$ \\
Phenol & $<20 . \mathrm{ug} / 1$ & 20. & $065500000 \mathrm{~N}$ \\
2-Nitrophenol & $<20 . \mathrm{ug} / 1$ & 20. & $065100000 \mathrm{~N}$ \\
2,4-Dimethylphenol & $<20 . \mathrm{ug} / 1$ & 20. & $064800000 \mathrm{~N}$ \\
2,4-Dichlorophenol & $<20 . \mathrm{ug} /$ & 20. & $064700000 \mathrm{~N}$ \\
4-Chloro-3-methylphenol & $<20 . \mathrm{ug} /$ & 20. & $065300000 \mathrm{~N}$ \\
2,4,6-Trichlorophenol & $<20 . \mathrm{ug} /$ & 20. & $065600000 \mathrm{~N}$ \\
2,4-Dinitrophenol & $<50 . \mathrm{ug} / 1$ & 50. & $065000000 \mathrm{~N}$ \\
4-Nitrophenol & $<50 . \mathrm{ug} / 1$ & 50. & $065200000 \mathrm{~N}$ \\
2-Methyl-4,6-dinitrophenol & $<50 . \mathrm{ug} / 1$ & 50. & $064900000 \mathrm{~N}$ \\
Pentachlorophenol & $<50 . \mathrm{ug} / 1$ & 50. & $065400000 \mathrm{~N}$
\end{tabular}


Well Number: CSD-13D

Water Sample Number: $\$ 856$

Collected on: April 5, 1989

Table 2. Lancaster Laboratories, Inc. Analysis Report of Water Samples from CSD-13D

\begin{tabular}{|c|c|c|c|}
\hline Base Neutrals & $\begin{array}{c}\text { Result } \\
\text { as Received }\end{array}$ & $\begin{array}{c}\text { Limit of } \\
\text { Quantitation }\end{array}$ & Lab Code \\
\hline Anthracene & $<20 . u g / 1$ & 20 & $065900000 \mathrm{~N}$ \\
\hline 1-n-butyl phthalate & $<20$. ug/l & 20. & $068200000 \mathrm{~N}$ \\
\hline Fluoranthene & $<20 . \mathrm{ug} / 1$ & 20. & $068700000 \mathrm{~N}$ \\
\hline Pyrene & $<20 . \mathrm{ug} / 1$ & 20. & $070100000 \mathrm{~N}$ \\
\hline Benzidine & $<50 . \mathrm{ug} / 1$ & 50. & $066000000 \mathrm{~N}$ \\
\hline Benzyl phthalate & $<20 . \mathrm{ug} / 1$ & 20. & $067100000 \mathrm{~N}$ \\
\hline Benzo ( $\alpha$ ) anthracene & $<20 . \mathrm{ug} / 1$ & 20. & $066100000 \mathrm{~N}$ \\
\hline Chrysene & $<20 . u g / 1$ & 20. & $067400000 \mathrm{~N}$ \\
\hline 1,3 Dichlorobenzidine & $<50 . u g / 1$ & 50. & $067900000 \mathrm{~N}$ \\
\hline *Cis (2-ethylhexyl) phthalate & $2,630 . \mathrm{ug} / 1$ & 20. & $066900000 \mathrm{~N}$ \\
\hline Di-n-octyl phthalate & $<20 . u g / 1$ & 20. & $068500000 \mathrm{~N}$ \\
\hline Benzo $(\beta)$ fluoranthene & $<20 . \mathrm{ug} /$ & 20. & $066300000 \mathrm{~N}$ \\
\hline Benzo (K) fluoranthene & $<20 . \mathrm{ug} / 1$ & 20. & $066500000 \mathrm{~N}$ \\
\hline Benzo $(\alpha)$ pyrene & $<20 . \mathrm{ug} / 1$ & 20. & $066200000 \mathrm{~N}$ \\
\hline Indeno $(1,2,3-\mathrm{cd})$ pyrene & $<20 . u g / 1$ & 20. & $069300000 \mathrm{~N}$ \\
\hline Dibenzo $(a, h)$ anthracene & $<20 . \mathrm{ug} / 1$ & 20. & $067500000 \mathrm{~N}$ \\
\hline Benzo (ghi) perylene & $<20$. ug/l & 20. & $066400000 \mathrm{~N}$ \\
\hline
\end{tabular}

*Due to suspected contamination, this sample was re-extracted and re-analyzed for bis (2-ethylhexyl) phthalate. The result from the re-analysis for this compound is 50 . ug/. The detection limit for this compound in the re-extract is 40 . ug/ (increased due to limited volume for re-analysis). Since the holding time had been exceeded, data from both extractions is reported. 
Well Number: CSD-13D

Water Sample Number: \#856

Collected on: April 5, 1989

Table 3. Lancaster Laboratories, Inc. Analysis Report of Water Samples from CSD-13D

\begin{tabular}{|c|c|c|c|}
\hline Base Neutrals & $\begin{array}{c}\text { Result } \\
\text { as Received }\end{array}$ & $\begin{array}{c}\text { Limit of } \\
\text { Quantitation }\end{array}$ & Lab Code \\
\hline N-Nitrosodimethylamine & $<20 . u g / 1$ & 20. & $069700000 \mathrm{~N}$ \\
\hline cis (2-chloroethyl) ether & $<20 . u g / 1$ & 20. & $066700000 \mathrm{~N}$ \\
\hline 1,3-Dichlorobenzene & $<20 . u g / 1$ & 20. & $067700000 \mathrm{~N}$ \\
\hline 1,4-Dichlorobenzene & $<20 . u g / 1$ & 20. & $067800000 \mathrm{~N}$ \\
\hline 1,2-Dichlorobenzene & $<20 . u g / 1$ & 20. & $067600000 \mathrm{~N}$ \\
\hline cis (2-chloroisopropyl) ether & $<20 . u g / 1$ & 20. & $066800000 \mathrm{~N}$ \\
\hline Hexachloroethane & $<20 . \mathrm{ug} / 1$ & 20. & $069200000 \mathrm{~N}$ \\
\hline N-nitrosodi-n-propylamine & $<20 . \mathrm{ug} / 1$ & 20. & $069800000 \mathrm{~N}$ \\
\hline Nitrobenzene & $<20 . \mathrm{ug} /$ & 20. & $069600000 \mathrm{~N}$ \\
\hline Isophorone & $<20 . \mathrm{ug} / \mathrm{l}$ & 20. & $069400000 \mathrm{~N}$ \\
\hline Bis (2-chloroethoxy) methane & $<20 . \mathrm{ug} / 1$ & 20. & $066600000 \mathrm{~N}$ \\
\hline 1,2,4-Trichlorobenzene & $<20 . \mathrm{ug} / \mathrm{l}$ & 20. & $070200000 \mathrm{~N}$ \\
\hline Naphthalene & $<20 . \mathrm{ug} / \mathrm{l}$ & 20. & $069500000 \mathrm{~N}$ \\
\hline Hexachlorobutadiene & $<20 . \mathrm{ug} / 1$ & 20. & $069000000 \mathrm{~N}$ \\
\hline Hexachlorocyclopentadiene & $<20 . u g / 1$ & 20. & $069100000 \mathrm{~N}$ \\
\hline 2-Chloronaphthalene & $<20 . u g / 1$ & 20. & $067200000 \mathrm{~N}$ \\
\hline Acenaphthylene & $<20$.ug/ & 20. & $065800000 \mathrm{~N}$ \\
\hline Dimethyl phthalate & $<20 . u g / 1$ & 20. & $068100000 \mathrm{~N}$ \\
\hline 2,6-Dinitrotoluene & $<20$. ug/ & 20. & $068400000 \mathrm{~N}$ \\
\hline Acenaphthene & $<20$. ug $/$ & 20. & $065700000 \mathrm{~N}$ \\
\hline 2,4-Dinitrotoluene & $<20 . u g / 1$ & 20. & $068300000 \mathrm{~N}$ \\
\hline Fluorene & $<20 . u g / 1$ & 20. & $068800000 \mathrm{~N}$ \\
\hline 4-Chlorophenyl phenyl ether & $<20 . u g / 1$ & 20. & $067300000 \mathrm{~N}$ \\
\hline Diethyl phthalate & $<20 . \mathrm{ug} / 1$ & 20. & $068000000 \mathrm{~N}$ \\
\hline 1,2-Diphenylhydrazine & $<20 . u g / 1$ & 20. & $068600000 \mathrm{~N}$ \\
\hline N-Nitrosodiphenylamine & $<20 . \mathrm{ug} / \mathrm{l}$ & 20. & $069900000 \mathrm{~N}$ \\
\hline 4-Bromophenyl phenyl ether & $<20 . u g / 1$ & 20. & $067000000 \mathrm{~N}$ \\
\hline Hexachlorobenzene & $<20 . \mathrm{ug} / 1$ & 20. & $068900000 \mathrm{~N}$ \\
\hline Phenanthrene & $<20 . \mathrm{ug} / \mathrm{l}$ & 20. & $070000000 \mathrm{~N}$ \\
\hline
\end{tabular}


Date: April 28, 1989

Well Number: CSD-13D

Laboratory Number: M856

Sample Description: Water Sample

Date Received: March 28, 1989

Table 4. Lancaster Laboratories, Inc. Analysis Report of Water Samples from CSD-13D

\begin{tabular}{|c|c|c|}
\hline Compound & $\begin{array}{c}\text { Concentration } \\
\mu g / 1\end{array}$ & $\begin{array}{l}\text { Limit of Detection } \\
\qquad \mu \mathrm{g} / \mathbf{1}\end{array}$ \\
\hline Chloromethane & $<10$ & 10 \\
\hline Bromomethane & $<10$ & 10 \\
\hline Vinyl chloride & $<10$ & 10 \\
\hline Chloroethane & $<10$ & 10 \\
\hline Methylene chloride & $7(B=2)$ & 5 \\
\hline 1,1-Dichloroethene & $<5$ & 5 \\
\hline 1,1-Dichloroethane & $<5$ & 5 \\
\hline Trans-1,2-dichloroethene & $1(\mathrm{~J})$ & 5 \\
\hline Chloroform & $<5$ & 5 \\
\hline 1,2-Dichloroethane & $<5$ & 5 \\
\hline 1,1,1-Trichloroethane & $1(J)$ & 5 \\
\hline Carbon Tetrachloride & $<5$ & 5 \\
\hline Bromodichloromethane & $<5$ & 5 \\
\hline 1,2-Dichloropropane & $<5$ & 5 \\
\hline cis-1,3-dichloropropene & $<5$ & 5 \\
\hline Trichloroethene & $3(J)$ & 5 \\
\hline Dibromochloromethane & $<5$ & 5 \\
\hline 1,1,2-Trichloroethane & $<5$ & 5 \\
\hline Benzene & 5 & 5 \\
\hline 2-Chloroethylvinylether & $<10$ & 10 \\
\hline Trans-1,3-dichloropropene & $<5$ & 5 \\
\hline Bromoform & $<5$ & 5 \\
\hline Tetrachloroethene & $<5$ & 5 \\
\hline 1,1,2,2-Tetrachloroethane & $<5$ & 5 \\
\hline Toluene & $<5$ & 5 \\
\hline Chlorobenzene & $<5$ & 5 \\
\hline Ethylbenzene & $<5$ & 5 \\
\hline Total xylenes & $<5$ & 5 \\
\hline
\end{tabular}

$\mathrm{J}=$ Below detection limit

$\mathrm{B}=$ Found in method blank at level indicated

Method of Analysis: EPA Method 624 + Xylenes using HP Gas Chromatograph/Mass Spectrometer 
Date: April 25, 1989

Well Number: Field Blank

Laboratory Number: M857

Sample Description: Water Sample

Date Received: March 28, 1989

Table 5. Lancaster Laboratories, Inc. Analysis Report of Water Samples from the Well Blank

\begin{tabular}{|c|c|c|}
\hline Compound & $\begin{array}{c}\text { Concentration } \\
\mu g / 1\end{array}$ & $\begin{array}{c}\text { Limit of Detection } \\
\mu \mathrm{g} / \mathbf{1}\end{array}$ \\
\hline Chloromethane & $<10$ & 10 \\
\hline Bromomethane & $<10$ & 10 \\
\hline Vinyl chloride & $<10$ & 10 \\
\hline Chloroethane & $<10$ & 10 \\
\hline Methylene chloride & $2(\mathrm{~J}, \mathrm{~B}=2)$ & 5 \\
\hline 1,1-Dichloroethene & $<5$ & 5 \\
\hline 1,1-Dichloroethane & $<5$ & 5 \\
\hline trans-1,2-dichloroethene & $<5$ & 5 \\
\hline Chloroform & $<5$ & 5 \\
\hline 1,2-Dichloroethane & $<5$ & 5 \\
\hline 1,1,1-Trichloroethane & $<5$ & 5 \\
\hline Carbon tetrachloride & $<5$ & 5 \\
\hline Bromodichloromethane & $<5$ & 5 \\
\hline 1,2-Dichloropropane & $<5$ & 5 \\
\hline cis-1,3-dichloropropene & $<5$ & 5 \\
\hline Trichloroethene & $<5$ & 5 \\
\hline Dibromochloromethane & $<5$ & 5 \\
\hline 1,1,2-Trichloroethane & $<5$ & 5 \\
\hline Benzene & 5 & 5 \\
\hline 2-Chloroethylvinylether & $<10$ & 10 \\
\hline trans-1,3-dichloropropene & $<5$ & 5 \\
\hline Bromoform & $<5$ & 5 \\
\hline Tetrachloroethene & $<5$ & 5 \\
\hline 1,1,2,2-Tetrachloroethane & $<5$ & 5 \\
\hline Toluene & $<5$ & 5 \\
\hline Chlorobenzene & $<5$ & 5 \\
\hline Ethylbenzene & $<5$ & 5 \\
\hline Total xylenes & $<5$ & 5 \\
\hline
\end{tabular}

$\mathrm{J}=$ Below detection limit

$\mathbf{B}=$ Found in method blank at level indicated

Method of Analysis: EPA Method 624 + Xylenes using HP5970 Gas Chromatograph/Mass Spectrometer 
Date: April 28, 1989

Well Number: CSD-11D

Laboratory Number: M858

Sample Description: Water Sample

Date Received: March 28, 1989

Table 6. Lancaster Laboratories, Inc. Analysis Report of Water Samples from CSD-11D

\begin{tabular}{lcc}
\multicolumn{1}{c}{ Compound } & $\begin{array}{c}\text { Concentration } \\
\mu \mathrm{g} / \mathbf{1}\end{array}$ & $\begin{array}{c}\text { Limit of Detection } \\
\boldsymbol{\mu g} / \mathbf{1}\end{array}$ \\
\hline Chloromethane & $<10$ & 10 \\
Bromomethane & $<10$ & 10 \\
Vinyl chloride & $<10$ & 10 \\
Chloroethane & $<10$ & 10 \\
Methylene chloride & $15(\mathrm{~B}=2)$ & 5 \\
1,1-Dichloroethene & $<5$ & 5 \\
1,1-Dichloroethane & $<5$ & 5 \\
Trans-1,2-dichloroethene & $<5$ & 5 \\
Chloroform & $<5$ & 5 \\
1,2-Dichoroethane & $<5$ & 5 \\
1,1,1-Trichloroethane & $3(\mathrm{~J})$ & 5 \\
Carbon tetrachloride & $<5$ & 5 \\
Bromodichloromethane & $<5$ & 5 \\
1,2-Dichloropropane & $<5$ & 5 \\
cis-1,3-dichloropropene & $<5$ & 5 \\
Trichloroethene & $2(\mathrm{~J})$ & 5 \\
Dibromochloromethane & $<5$ & 5 \\
1,1,2-Trichloroethane & $<5$ & 5 \\
Benzene & $<5$ & 5 \\
2-chloroethylvinylether & $<10$ & 10 \\
Trans-1,3-dichloropropene & $<5$ & 5 \\
Bromoform & $<5$ & 5 \\
Tetrachloroethene & $<5$ & 5 \\
1,1,2,2-Tetrachloroethane & $<5$ & 5 \\
Toluene & $<5$ & 5 \\
Chlorobenzene & $<5$ & 5 \\
Ethylbenzene & $<5$ & 5 \\
Total xylenes & $<5$ & 5
\end{tabular}

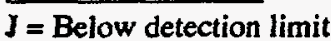

$B=$ Found in method blank at level indicated

Method of Analysis: EPA Method 624 + Xylenes using HP 5970 Gas Chromatograph/Mass Spectrometer 
Date: April 28, 1989

Well Number: CSD-4D

Laboratory Number: M859

Sample Description: Water Sample

Date Received: March 28, 1989

Table 7. Lancaster Laboratories, Inc. Analysis Report of Water Samples from CSD-4D

\begin{tabular}{lcc}
\multicolumn{1}{c}{ Compound } & $\begin{array}{c}\text { Concentration } \\
\mu \mathrm{g} / \mathbf{1}\end{array}$ & $\begin{array}{c}\text { Lmit of Detection } \\
\boldsymbol{\mu g} / \mathbf{1}\end{array}$ \\
\hline Chloromethane & $<10$ & 10 \\
Bromomethane & $<10$ & 10 \\
Vinyl chloride & $<10$ & 10 \\
Chloroethane & $<10$ & 10 \\
Methylene chloride & $1(\mathrm{~J}, \mathrm{~B}=2)$ & 5 \\
1,1-Dichloroethene & $<5$ & 5 \\
1,1-Dichloroethane & $<5$ & 5 \\
trans-1,2-dichloroethene & $<5$ & 5 \\
Chloroform & $<5$ & 5 \\
1,2-Dichoroethane & $<5$ & 5 \\
1,1,1-Trichloroethane & $<5$ & 5 \\
Carbon tetrachloride & $<5$ & 5 \\
Bromodichloromethane & $<5$ & 5 \\
1,2-Dichloropropane & $<5$ & 5 \\
cis-1,3-dichloropropene & $<8$ & 5 \\
Trichloroethene & $<8$ & 5 \\
Dibromochloromethane & $<5$ & 5 \\
1,1,2-Trichloroethane & $<5$ & 5 \\
Benzene & $<5$ & 5 \\
Trans-1,3-dichloropropene & $<10$ & 10 \\
2-Chloroethylvinylether & $<5$ & 5 \\
Bromoform & $<5$ & 5 \\
Tetrachloroethene & $<(J)$ & 5 \\
1,1,2,2-Tetrachloroethane & $<5$ & 5 \\
Toluene & $<5$ & 5 \\
Chlorobenzene & $<5$ & 5 \\
Ethylbenzene & $<5$ & 5 \\
Total xylenes & & 5
\end{tabular}

$J=$ Below detection limit

$B=$ Found in method blank at level indicated

Method of Analysis: EPA Method 624 + Xylenes using HP 5970 Gas Chromatograph/Mass Spectrometer 
Date: April 28, 1989

Well Number: Trip Blank

Laboratory Number: M860

Sample Description: Water Sample

Date Received: March 28, 1989

Table 8. Lancaster Laboratories, Inc. Analysis Report of Water Samples from the Trip Blank

\begin{tabular}{|c|c|c|}
\hline Compound & $\begin{array}{c}\text { Concentration } \\
\mu g / 1\end{array}$ & $\begin{array}{c}\text { Limit of Detection } \\
\qquad \mu g / 1\end{array}$ \\
\hline Chloromethane & $<F 10$ & 10 \\
\hline Bromomethane & $<10$ & 10 \\
\hline Vinyl chloride & $<10$ & 10 \\
\hline Chloroethane & $<10$ & 10 \\
\hline Methylene chloride & $3(\mathrm{~J}, \mathrm{~B}=2)$ & 5 \\
\hline 1,1-Dichloroethene & $<5$ & 5 \\
\hline 1,1-Dichloroethane & $<5$ & 5 \\
\hline trans-1,2-dichloroethene & $<5$ & 5 \\
\hline Chloroform & $<5$ & 5 \\
\hline 1,2-Dichloroethane & $<5$ & 5 \\
\hline 1,1,1-Trichloroethane & $<5$ & 5 \\
\hline Carbon tetrachloride & $<5$ & 5 \\
\hline Bromodichloromethane & $<5$ & 5 \\
\hline 1,2-Dichloropropane & $<5$ & 5 \\
\hline cis-1,3-dichloropropene & $<5$ & 5 \\
\hline Trichloroethene & $<5$ & 5 \\
\hline Dibromochloromethane & $<5$ & 5 \\
\hline $1,1,2-$ Trichloroethane & $<5$ & 5 \\
\hline Benzene & $<5$ & 5 \\
\hline trans-1,3-dichloropropene & $<10$ & 10 \\
\hline 2-Chloroethylvinylether & $<5$ & 5 \\
\hline Bromoform & $<5$ & 5 \\
\hline Tetrachloroethene & $<5$ & 5 \\
\hline 1,1,2,2-Tetrachloroethane & $<5$ & 5 \\
\hline Toluene & $<5$ & 5 \\
\hline Chlorobenzene & $<5$ & 5 \\
\hline Ethylbenzene & $<5$ & 5 \\
\hline Total xylenes & $<5$ & 5 \\
\hline
\end{tabular}

$\mathbf{J}=$ Below detection limit

$\mathrm{B}=$ Found in method blank at level indicated

Method of Analysis: EPA Method 624 + Xylenes using HP 5970 Gas Chromatograph/Mass Spectrometer 
Appendix II

Soil Microbiology Counts 
Date: February 2, 1989

Laboratory Number: 038035 and 038037 - MS06 to M543

Samples Description: Core Samples

Date Received: December 20, 21, and 22, 1988

Sample From: Savannah River Plant, Aiken SC

Table 1. Analysis Report

\begin{tabular}{|c|c|c|c|c|}
\hline \multirow[b]{2}{*}{$\log *$} & \multirow[b]{2}{*}{ Core * } & \multirow[b]{2}{*}{ Depth Feet } & \multicolumn{2}{|c|}{ CFU/g } \\
\hline & & & Total Counts • & Diesel Utilizers ** \\
\hline 534 & 1.1 & 47 & $<100$ & $<200$ \\
\hline 535 & $1-2$ & 50 & $<100$ & $<200$ \\
\hline 536 & $1-3$ & 52 & $<100$ & $<200$ \\
\hline 537 & $1-4$ & 55 & 100 & $<200$ \\
\hline 538 & $1-5$ & 61 & $<100$ & $<200$ \\
\hline $538 D$ & $1-5$ & 61 & $<100$ & $<200$ \\
\hline 539 & $2-1$ & 27 & 1400 & $<200$ \\
\hline 540 & $2-2$ & 30 & 1200 & $<200$ \\
\hline 541 & $2-3$ & 31 & 500 & $<200$ \\
\hline 542 & $2-4$ & 36 & $<100$ & $<200$ \\
\hline 543 & $2-5$ & 46 & 200 & $<200$ \\
\hline 543D & $2-5$ & 46 & 100 & $<200$ \\
\hline 506 & $3-1$ & 3 & 2800 & 200 \\
\hline 507 & $3-2$ & 7 & 1000 & $<200$ \\
\hline 508 & $3-3$ & 12 & $<100$ & 2200 \\
\hline
\end{tabular}

100 is the minimum number of total bacteria that can be counted by this procedure

$* 200$ is the minimum of diesel utilizers that can be counted by this procedure

" $\mathrm{D}$ " indicates laboratory duplicate 
Date: February 1, 1989

Laboratory Number: 38036 - M509 to M533

Sample Description: Core Samples

Date Received: December 17, 1988

Sample From: Savannah River Plant, Aiken SC

Chain of Custody: Yes

Thble 2. Analysis Report

\begin{tabular}{ccccc} 
& & & \multicolumn{2}{c}{ CFU/g } \\
\cline { 4 - 5 } Log * & Core * & Depth Feet & $\begin{array}{c}\text { Total } \\
\text { Cownts * }\end{array}$ & $\begin{array}{c}\text { Dlesel } \\
\text { Utilizers** }\end{array}$ \\
\hline 509 & $4-1$ & 2.5 & 4600 & $<200$ \\
510 & $4-2$ & 4 & 1000 & $<200$ \\
511 & $4-3$ & 12 & $<100$ & 200 \\
512 & $4-4$ & 17 & $<100$ & 200 \\
513 & $4-5$ & 22 & $<100$ & 200 \\
514 & $4-6$ & 25 & $<100$ & $<200$ \\
515 & $4-7$ & 28 & $<100$ & 200 \\
516 & $4-8$ & 31 & $<100$ & 200 \\
517 & $4-9$ & 34 & $<100$ & 200 \\
518 & $4-10$ & 37 & $<100$ & 200 \\
519 & $4-11$ & 40 & $<100$ & $<200$ \\
520 & $4-12$ & 43 & 100 & $<200$ \\
521 & $4-13$ & 46 & $<100$ & $<200$ \\
522 & $4-14$ & 48 & $<100$ & $<200$ \\
523 & $4-15$ & 52 & $<100$ & $<200$ \\
524 & $4-16$ & 55 & $<100$ & $<200$ \\
525 & $4-17$ & 58 & $<100$ & $<200$ \\
526 & $4-18$ & 61 & 100 & $<200$ \\
527 & $4-19$ & 64 & 400 & $<200$ \\
528 & $4-20$ & 67 & $<100$ & $<200$ \\
529 & $4-21$ & 70 & $<100$ & $<200$ \\
530 & $4-22$ & 73 & $<100$ & $<200$ \\
531 & $4-23$ & 76 & $<100$ & 200 \\
532 & $4-24$ & 79 & $<100$ & $<200$ \\
533 & $4-25$ & 82 & $<100$ & $<200$ \\
& & & &
\end{tabular}

* 100 is the minimum number of total bacteria that can be counted by this procedure

**200 is the minimum number of diesel utilizers that can be counted by this procedure 
Date: January 31, 1989

Laboratory Number: 038035 and 036038 - M496 to M569

Sample Description: Core Samples

Date Received: December 15, 16, 1988 and January 4, 1989

Sample From: Savannah River Plant, Aiken SC

Chain of Custody: Yes

Table 3. Analysis Report

\begin{tabular}{|c|c|c|c|c|}
\hline \multirow[b]{2}{*}{$\log \#$} & \multirow[b]{2}{*}{ Core " } & \multirow[b]{2}{*}{ Depth Feet } & \multicolumn{2}{|c|}{ CFU/g } \\
\hline & & & $\begin{array}{c}\text { Total } \\
\text { Counts * }\end{array}$ & $\begin{array}{c}\text { Diesel } \\
\text { Utillzers }\end{array}$ \\
\hline 496 & $5-1$ & $1-3$ & 2800 & 200 \\
\hline 497 & $5-2$ & 3 & 520,000 & 22,400 \\
\hline 498 & $5-2$ & $7-9$ & 400 & $<200$ \\
\hline 499 & $5-3$ & $10-12$ & 1000 & $<200$ \\
\hline 500 & $6-1$ & 2.5 & 1500 & $<200$ \\
\hline 501 & $6-2$ & 7 & 4000 & $<200$ \\
\hline 502 & $6-3$ & 12 & $<100$ & $<200$ \\
\hline 503 & $7-1$ & 4 & $<100$ & $<200$ \\
\hline 504 & $7-2$ & 8 & $<100$ & $<200$ \\
\hline 505 & $7-3$ & 12 & $<100$ & 400 \\
\hline 562 & $8-1$ & 27 & 2000 & 800 \\
\hline 563 & $8-2$ & 32 & $<100$ & $<200$ \\
\hline 564 & $8-3$ & 37 & 100 & $<200$ \\
\hline 565 & $8-4$ & 42 & $<100$ & $<200$ \\
\hline 566 & $8-5$ & 57 & $<100$ & $<200$ \\
\hline 567 & $8-6$ & 67 & $<100$ & $<200$ \\
\hline 567D & $8-6$ & 67 & $<100$ & $<200$ \\
\hline 569 & $8-7$ & 77 & $<100$ & $<200$ \\
\hline
\end{tabular}

100 is the minimum number of total bacteria that can be counted by this procedure

* 200 is the minimum of diesel utilizers that can be counted by this procedure

"D" indicates laboratory duplicate 
Date: February 16, 1989

Laboratory Number: 038038 and 038046 - M570 to M586

Sample Description: Core Samples

Date Received: January 6, 9, and 11, 1989

Sample From: Savannah River Plant, Aiken SC

Chain of Custody: Yes

Table 4. Analysis Report

\begin{tabular}{lcccc} 
& & & \multicolumn{2}{c}{ CFU/g } \\
\cline { 4 - 5 } Log \# & Core * & Depth Feet & $\begin{array}{r}\text { Total } \\
\text { Counts * }\end{array}$ & Diesel Utilizers ** \\
\hline M576 & $9-1$ & 8 & 200 & 200 \\
M577 & $9-2$ & 20 & $<100$ & $<200$ \\
M578 & $9-3$ & 30 & $<100$ & $<200$ \\
M579 & $9-4$ & 38 & $<100$ & $<200$ \\
M580 & $9-5$ & 50 & 100 & $<200$ \\
M581 & $9-6$ & 56 & 1000 & 400 \\
M582 & $9-7$ & 60 & 100 & $<200$ \\
M583 & $9-8$ & 66 & 300 & 200 \\
M584 & $9-9$ & 72 & $<100$ & 200 \\
M585 & $9-10$ & 76 & $<100$ & $<200$ \\
M586 & $9-11$ & 80 & 100 & $<200$ \\
& & & & $<200$ \\
570 & $10-1$ & 32 & $<100$ & $<200$ \\
571 & $10-2$ & 42 & $<100$ & $<200$ \\
572 & $10-3$ & 52 & 100 & 3800 \\
573 & $10-4$ & 57 & 4200 & 600 \\
574 & $10-5$ & 62 & $<100$ & $<200$ \\
575 & $10-6$ & 67 & $<100$ &
\end{tabular}

* 100 is the minimum number of total bacteria that can be counted by this procedure

** 200 is the minimum number of diesel utilizers that can be counted by this procedure 
Date: February 16, 1989

Laboratory Number: 038047 - M593 to M603

Sample Description: Core Samples

Date Received: January 12, 1989

Sample From: Savannah River Plant, Aiken SC

Chain of Custody: Yes

Table 5. Analysis Report

\begin{tabular}{lcccc} 
& & & \multicolumn{2}{c}{ CFU/g } \\
\cline { 4 - 5 } Log * & Core * & Depth Feet & $\begin{array}{c}\text { Total } \\
\text { Counts * }\end{array}$ & Diesel Utilizers ** \\
\hline M593 & $11-1$ & 6 & 300 & $<200$ \\
M594 & $11-2$ & 10 & $<100$ & $<200$ \\
M595 & $11-3$ & 16 & 100 & $<200$ \\
M596 & $11-4$ & 24 & $<100$ & 200 \\
M597 & $11-5$ & 30 & $<100$ & 2400 \\
M598 & $11-6$ & 36 & $<100$ & 200 \\
M599 & $11-7$ & 42 & $<100$ & 200 \\
M600 & $11-8$ & 48 & $<100$ & $<200$ \\
M601 & $11-9$ & 54 & 100 & $<200$ \\
M602 & $11-10$ & 62 & $<100$ & $<200$ \\
M603 & $11-11$ & 70 & 100 & $<200$
\end{tabular}

- 100 is the minimum number of total bacteria that can be counted by this procedure

**200 is the minimum number of diesel utilizers that can be counted by this procedure 
Date: February 2, 1989

Laboratory Number: 038037 and 038038 - M544 to M561

Sample Description: Core Samples

Date Received: December 23, 1988 and January 4, 1989

Sample From: Savannah River Plant, Aiken SC

Chain of Custody: Yes

Table 6. Analysis Report

\begin{tabular}{ccccc} 
& & & \multicolumn{2}{c}{ CFU/g } \\
\cline { 4 - 5 } Log \# & Core * & Depth Feet & $\begin{array}{c}\text { Totsl } \\
\text { Counts * }\end{array}$ & Diesel Utilizers ** \\
\hline 556 & $12-1$ & 32 & $<100$ & $<200$ \\
557 & $12-2$ & 37 & $<100$ & $<200$ \\
558 & $12-3$ & 42 & $<100$ & 200 \\
559 & $12-4$ & 47 & 300 & $<200$ \\
560 & $12-5$ & 60 & 100 & 200 \\
561 & $12-6$ & 65 & $<100$ & 200 \\
& & & & \\
544 & $13-1$ & 7 & 300 & $<200$ \\
545 & $13-2$ & 12 & $<100$ & 200 \\
546 & $13-3$ & 17 & 600 & 200 \\
547 & $13-4$ & 22 & 200 & 1000 \\
548 & $13-5$ & 27 & $<100$ & $<200$ \\
549 & $13-6$ & 32 & $<100$ & $<200$ \\
550 & $13-7$ & 37 & 100 & $<200$ \\
551 & $13-8$ & 42 & $<100$ & $<200$ \\
552 & $13-9$ & 47 & 100 & $<200$ \\
553 & $13-10$ & 52 & $<100$ & $<200$ \\
554 & $13-11$ & 57 & $<100$ & $<200$ \\
555 & $13-12$ & 62 & $<100$ & $<200$
\end{tabular}

* 100 is the minimum number of total bacteria that can be counted by this procedure

**200 is the minimum number of diesel utilizers that can be counted by this procedure 
Date: May 23, 1989

Laboratory Number: 038089 - M856 to M860

Sample Description: Water Samples

Date Received: March 28, 1989

Sample From: Savannah River Plant, Aiken SC

Chain of Custody: Yes

Table 7. Analysis Report

\begin{tabular}{lrrr} 
Log * & Well * & Total Counts & Diesel Utilizers \\
\hline M856 & 13 & 3600 & 4200 \\
M857 & FB* & 9 & 20 \\
M858 & 11 & 44000 & 14800 \\
M859 & 4 & 0 & $<10^{1}$ \\
M859D & 4 & 0 & $<10$ \\
M860 & TB* & 0 & $<10$
\end{tabular}

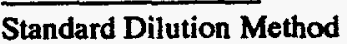

${ }^{1}$ Minimum number of diesel utilizer which can by counted by this procedure is 10 organisms per milliliter *FB = Field Blank

*TB = Trip Blank 
Date: May 23, 1989

Laboratory Number: 038089 - M856 to M860

Sample Description: Water Samples

Date Received: March 28, 1989

Sample From: Savannah River Plant, Aiken SC

Chain of Custody: Yes

Table 8. Analysis Report

\begin{tabular}{lrc}
$\log *$ & Well * & Direct Counts \\
\hline M856 & 13 & 11,498 \\
M857 & FB* & $<40^{1}$ \\
M858 & 11 & 5970 \\
M859 & 4 & 5105 \\
M859D & 4 & 9894 \\
M860 & TB* & $<40$
\end{tabular}

Cells stained with acridine orange, collected on a 0.45 um Erglan black prestained filter, and counted by epiflourescent microscopy.

${ }^{1}$ Minimum number of direct counts which can by made by this procedure is 40 organisms per milliliter

* FB = Field Blank

- TB = Trip Blank 